\title{
The Effectiveness of a Proposed Internet- Based Collaborative Tasks Program in Developing EFL Speaking Skills among Egyptian University Level Students Ebtihal A. Helal, Ph.D. \\ TEFL Lecturer \\ Faculty of Languages, October Modern Sciences \& Arts University Abstract:
}

The aim of the current study was to help EFL first year intensive English course students at October Modern Sciences \& Arts University develop the necessary speaking sub-skills through a proposed Internet- based collaborative tasks program. These tasks included (1) watching, retelling and commenting on online digital stories, (2) watching online videos on argumentative topics and having debates based on these videos and (3) using different internet sources to give group multi-media presentations highlighting the causes, effects and possible solutions of varied problems. The study followed the quasi- experimental pretest-posttest one group design. The study group consisted of thirty students who were randomly selected for the purpose of the current study. The experimental group was taught by the researcher throughout the Spring Semester of the academic year 2017- 2018 according to the proposed program. The study tools included a checklist for determining the necessary speaking sub-skills, a pre- /post- speaking test, an analytical rubric for marking the students' oral performance on the pre-/ post- test and the proposed program. Comparing the pre-/ post-test speaking performance of the study group indicated that there were statistically significant differences between the pre-test and post- test scores in favour of the post- test scores. Therefore, it was concluded that the proposed program proved to be effective in developing the study group students' overall speaking performance as well as in developing each speaking sub-skill.

Key Words: Internet- based collaborative learning, Task-Based Instruction, speaking sub-skills, debates, digital storytelling, oral presentations, EFL university level learners

\section{Introduction}

Speaking is a main productive language skill through which EFL learners can express their ideas and points of view. In almost any setting, speaking is considered the most frequently used language skill. Therefore, learners of a foreign language are usually "referred to as 'speakers' of that language" (Ur, 1996, p. 120). In addition, speaking is closely related to listening as two interrelated means of achieving effective communication whether between native or non-native English speakers. Moreover, speaking boosts EFL learners' self- confidence by offering them tangible evidence that they are making progress in the target language. Therefore, success in learning a foreign language is usually measured in terms of L2 learners' ability to carry out a conversation in this language (Nunan, 1999). 
Due to the considerable importance of speaking, EFL university level instructors attempt to develop speaking sub-skills among their students. However, as a complex skill, speaking is not an easy skill to develop (Ur, 1996; Brown, 2007a). It needs time, effort and constant practice. It, also, involves varied sub-skills such as pronunciation, fluency, vocabulary, grammar, pragmatic competence, strategic competence and sociolinguistic competence (Canale, 1984; Tarone \& Yule, 1989; Scarcella \& Oxford, 1992; Brown, 2007a). Hence, developing EFL speaking skills among university level learners needs innovative instructors who would use varied engaging techniques to create authentic speaking tasks that are very much likely to be enacted in real life situations (Nunan, 2004).

Going back in time, it can be noticed that since the Grammar Translation Method failure to develop learners' ability to speak effectively using the target language, interest in developing speaking skills has been the focus of many EFL teaching methods and approaches such as the Direct Method, the Audio-Lingual Method and the Communicative Language Teaching Approach (Larsen-Freeman, 2011). Also, as highlighted by Saville-Troike (2006) and Brown (2007b), some second language acquisition theories and hypotheses have stressed the impact of speaking and interaction on developing second language learners' linguistic proficiency levels. Among these theories and hypotheses are Vygotsky's (1978) Socio- Cultural Theory, Swain's (1995) Output Hypothesis and Long's (1996) Interaction Hypothesis.

While Vygotsky's Socio- Cultural Theory stresses the importance of interaction as a necessary- not just a facilitating- condition of second language acquisition, Swain (1995) maintains that it is through learners' output that they can notice the gap between what they know and what they should know. Besides, output helps learners to test their hypotheses, see whether their utterances work or not, seek feedback and reflect upon their linguistic knowledge (Swain, 1995 and 2005). According to Long's (1996) Interaction Hypothesis, interaction is a major contributor to second language acquisition as it helps learners develop their knowledge of language rules and conventions. Brown (2007 b) maintains that Long's Interaction Hypothesis reflects a social constructivist model to language acquisition where learners' interaction with their peers and the teacher helps their linguistic development.

Nowadays one of the effective instructional approaches to developing EFL speaking skill is Task- Based Instruction (Nunan, 1999 and 2004). It is based on the notion that when learners are asked to carry 


\section{Ebtihal A. Helal, Ph.D.}

out a meaningful real- life activity that has a specific outcome, they are more interactively involved in the learning process in a way that should foster their language skills (Brown, 2007a; Larsen-Freeman, 2011). Therefore, several scholars such as Nunan (2004), Brown (2007a) and Hendriani (2014) have recommended the use of Task- Based Instruction to develop EFL learners' speaking skills.

Recent research, also, has highlighted the positive impact of TaskBased Instruction in fostering university level EFL learners' speaking skills. Among the studies that stressed this idea are the studies of Kirkgöz (2011), Ismaili (2013), Ho and Long (2014), Ji (2014), Mohammadipour \& Rashid (2015), Hamouda (2016), Sariçoban \& Karakurt (2016) and Yousif (2017). In these studies, EFL university level students' substantial speaking skills development was attributed to the fact that Task- Based Instruction (a) minimized their speech anxiety, (b) promoted their self- confidence, (c) gave them a real reason for communicating in the target language, (d) enhanced their motivation, (e) engaged them in the language learning process and (f) created a more student- centered learning environment where they assumed more responsibility for their own learning. Furthermore, a significant finding was highlighted by Erten's \& Altay's (2009) study where it was concluded that as compared to topic- based group activities, Task- based group activities promoted more collaboration and interaction among EFL university level learners.

Also, as we live in the age of the Internet, Egyptian EFL university level learners can benefit a lot from this kind of Computer- Assisted Language Learning (CALL) as it (i) enhances learners' interaction, motivation and participation, (ii) adds the fun factor to the learning situation, (iii) offers authentic multimodal texts, videos, audios and numerous recent updated sources of information, (iv) empowers students to become more independent autonomous learners and (v) adds vitality as well as vividness to the EFL learning environment (Warschauer, Shetzer \& Meloni, 2000; Brown, 2007a). In addition, using the Internet encourages EFL learners to "collaborate with others to help construct new knowledge" (Warschauer, Shetzer \& Meloni, 2000, p.8).

When Internet- based speaking tasks are carried out in collaborative groups, this helps EFL learners benefit from each other. Thus, in such a collaborative task, when the more knowledgeable helps the less knowledgeable, students with low self- confidence, low risktaking ability and high anxiety level get enough scaffolding that can promote their speaking skills (Kobayashi, 2003; Garbati \& Mady, 2015), especially when the EFL instructor is offering enough guidance and 
support as highlighted in Vygotsky's (1978) zone of proximal development.

Reviewing previous studies on the impact of Internet- based collaborative tasks has revealed that some studies were conducted on its impact on developing writing skills such as the studies of Cizinauskiene, Daubariene and Marcinkoniene (2002) and Choi (2008). In addition, a study was conducted by Al-Rawahi and Al- Makhlafi (2015) on its impact on developing Omani EFL university level learners' reading, writing and attitude. To the researcher's best knowledge, no study was conducted using Internet- based collaborative tasks to develop EFL speaking skills among Egyptian university level learners. This was considered a gap in the literature; therefore, the current study is an attempt to bridge this gap.

However, remains an important issue related to the proper selection of the speaking tasks that can really engage Egyptian EFL university level learners. Bearing in mind the major characteristics that distinguish the age group of university level learners, these adult learners are characterized by substantial cognitive maturation that allows them to deal with abstract concepts (Saville-Troike, 2006; Brown, 2007a); they, also, display a tendency to analyze ideas due to the lateralization process (i.e., the growing dominance of the brain left hemisphere) (Littlewood,1998; Brown, 2007a). In addition, they are more selfconscious and like to save their face (public self- image) (Littlewood, 1998; Brown, 2007a).

Debates, giving multimedia oral presentations as well as retelling and commenting on online digital stories were selected by the researcher as suitable tasks for developing speaking skills among Egyptian EFL university level learners. Such a selection was based on the findings of previous studies that highlighted the positive impact of these tasks on developing EFL university learners' speaking skills such as the studies of Baghdasaryan (2012), Somdee (2012), Dekdouk (2013), Ben Alahem (2013), Kim (2014), Rokni \& Qarajeh (2014), Pardo (2014), Sabbah (2015), Fauzan (2016), Fauzi (2016) and Abdelmageed \& El- Naggar (2018). In addition, several scholars such as Celce-Murcia (2001), King (2002), Ebada (2009), Alasmari \& Ahmed (2013), Burek \& Losos (2014) and Christiansen \& Koelzer, (2016) have stressed the idea that debates, oral presentations and digital storytelling can enhance EFL learners' speaking skill. Furthermore, in the light of the researcher's experience as an EFL university level instructor for twelve years, it was quite evident 
that EFL university level learners become very much involved in tasks that require them to use the Internet in groups. Therefore, the current study made use of Internet- based collaborative tasks to develop Egyptian EFL university level learners' speaking skills.

Although learning to speak in the foreign language is commonly viewed as "the most vital of language skills" (Garbati \& Mady, 2015, p. 1763), Egyptian EFL university level learners face considerable difficulties while attempting to speak using the target language in communicative situations. These difficulties are attributed to a wide spectrum of factors; some of them are related to the nature of speaking as a demanding skill while other factors are related to the learners themselves, the traditional teaching methods adopted by quite a good number of EFL university level teachers as well as the lack of ample opportunities for interaction and exposure to the target language inside and outside the EFL classroom.

Before elaborating on these factors, it should be mentioned that negative impact of insufficient input and lack of exposure to the target language on learners' speaking skill is not only confined to Egyptian EFL learners. Rather, these are common factors in varied EFL contexts. Therefore, they were identified and highlighted by different scholars and researchers such as Shumin (2002) and Kara, Ayaz \& Dündar (2017). Also, traditional teaching methods of speaking were seen as a main impediment that hinders EFL speaking development among Arab EFL learners in Mennaai's (2013) study.

Starting with the nature of speaking, it is a complex multidimensional task (Sotoudehnama \& Hashamdar, 2016) that requires the mastery of several sub-skills to produce comprehensible coherent and meaningful utterances. In other words, a good EFL speaker has to master English grammar, pronunciation and vocabulary; he/ she has to be fluent, follow the conventions of coherence and cohesion, bear in mind the social context of his/ her utterance to select appropriate register according to the level of formality as well as use effective communication strategies to keep the flow of the conversation and compensate for any possible communication breakdown (Canale \& Swain, 1980; Bachman, 1990; Nunan, 1991; Scarcella \& Oxford, 1992; Scrivener, 2005; Brown, 2007a; Nation \& Newton, 2009).

In addition, speaking is a demanding mental skill for the human central nervous system (Bygate, 1998, p. 23); EFL speakers have to listen attentively to the other participant in the speech event and process his/ her utterances while thinking about their own ideas to give adequate responses to those utterances. This entails that speaking usually happens in the context of interlocutors' limited processing abilities resulting from 
the limitations of their working memory. Furthermore, speakers have to simultaneously monitor their speech adequacy and accuracy during their oral production and use enabling communicative strategies to keep the conversation going (Bygate, 1998, p. 23; Basturkmen, 2002, p. 28). As speaking happens in real time, once the speaker produces his/ her output, there is no chance for editing or revising; also, there is either no or very limited time to plan before actual speaking in real life situations (Foster, Tonkeyn \& Wigglesworth, 2000, p. 368; Bailey, 2006; Bygate, 2009). This results in the usual spoken language features of hesitations, false starts, overlaps, pauses and use of less specialized vocabulary (Brown, 2007a).

Factors related to Egyptian EFL university level learners might also contribute to their poor mastery of speaking skills. These factors are related to their insufficient practice of the speaking skill in real communicative situations. They are, also, related to some students' shyness, lack of motivation, fear of public speaking, use of the mother tongue in classroom interaction, low self- esteem, low self- confidence, low ambiguity tolerance and high anxiety levels. In such a condition, EFL learners' related factors have a negative impact on their oral communicative competence as indicated by Scarcella \& Oxford (1992) and Ur (1996).

\section{Context of the problem}

As the researcher observed some classes of first year intensive English course students at October Modern Sciences and Arts (MSA) University, it was evident that quite a good number of them were unwilling to speak in public using EFL. This might be attributed to varied reasons. First, most of them were unable to strike the necessary balance between accuracy and fluency. According to Krashen's Monitor Model (1982), they were mostly monitor under-users. This was obvious when they spoke in class as their oral performance exhibited evidence of remarkable problems related to incorrect pronunciation, lack of fluency, grammatical inaccuracy and inappropriate word choice.

Through classroom observations, it was also evident that the speaking activities used in class were quite mechanical and carried out for no authentic communicative purpose, and that might be the reason why students seemed quite uninterested, demotivated and unwilling to speak in class. Another significant reason is that many of these students were self- conscious; they cared about their public self- image. Thus, they were mostly reluctant to speak in public for fear of making mistakes. 
In addition, according to the English language placement test taken prior to the students' university admission, it is already recognized that intensive English course students do not meet the expected English language proficiency requirements. Hence, their overall poor EFL linguistic proficiency level had its negative impact on their speaking ability as well as on their willingness to participate in classroom interaction.

Observing the teaching methods and techniques adopted by EFL university level teachers in intensive English classes at Modern Sciences and Arts University enabled the researcher to see the problem from a different complementary perspective as it became obvious that:

(a) Speaking was rarely practised for a real world communicative purpose. It was not given due time and care by the instructors; most of the time it was overlooked to allocate more time to teaching grammar, vocabulary, reading and writing.

(b) Students were not properly prepared for classroom speaking activities, and when they spoke in class, they did not have time to reflect upon their speaking performance or do further exercises to enhance their pronunciation, grammar, vocabulary or fluency in the post- speaking phase.

(c) The speaking activities used were not motivating or challenging enough; they were either short dialogues or very few role plays. Debates, oral presentations and storytelling were not used in class.

(d)Despite the fact that these EFL learners were well- acquainted with computer and Internet usage, this advantage was not exploited in class to foster the learners' speaking skill.

(e) When practised in class, speaking activities were carried out with the whole class or in pairs.

(f) Collaborative speaking tasks were not adopted by the instructors. This might be due to two main reasons. Either these EFL teachers were not familiar with the procedures and stages of such tasks or they viewed them as time- consuming activities that needed a lot of preparation and classroom management with no guarantee that they 
might bring about desirable effects on learners' speaking proficiency.

To further reflect upon this problem, it should be admitted that teaching speaking to Egyptian EFL university learners is not easy as teachers have to come up with exciting real life, motivating tasks that engage learners in authentic communication for achieving a specific purpose. In addition, they have to help learners maintain the uneasy balance between fluency and accuracy while speaking; they, also, need to make sure that they mindfully and selectively correct learners' spoken errors without discouraging them from participating in future speaking activities (Brown, 2007a; Hendriani, 2014).

To investigate the problem deeply, the researcher administered a diagnostic speaking test on a random sample of twenty EFL intensive English course students at October Modern Sciences and Arts (MSA) University. Analyzing the results of this test confirmed that that these students suffered from overall poor speaking performance as well as obvious difficulties with regards to their speaking sub-skills. Such a result conforms with Al-Tamimi's and Attamimi's (2014) idea that most Arab EFL learners have difficulties in speaking, and these difficulties include the speaking sub-skills of grammar, vocabulary, pronunciation, fluency and comprehensibility. In addition, reviewing previous studies such as the studies of Torky (2006), Erten and Altay (2009) and Kirkgoz (2011) indicated the need for conducting research to foster speaking skills among EFL university level learners.

\section{Problem of the study}

The study problem was identified in Egyptian first year university level intensive English course students' poor mastery of the necessary EFL speaking sub-skills. This might be partly due to the lack of training in these essential skills. It might be also due to the traditional teaching methods and techniques adopted where students were not encouraged to practise meaningful real- life speaking tasks. Therefore, the current study attempted to develop the necessary EFL speaking skills among Egyptian first year university level intensive English course students through the use of a proposed Internet- based collaborative tasks program. In other words, this study attempted to provide answers to the following main question:

"What is the effectiveness of a proposed program designed in the light of Internet- based collaborative tasks in developing the necessary 
EFL speaking skills among Egyptian first year university level intensive English course students?"

From this main question, the following sub-questions emerged:

1. What are the necessary EFL speaking sub-skills for Egyptian university level first year intensive English course students?

2. What are the theoretical bases of a proposed program designed in the light of Internet- based collaborative tasks for developing the necessary speaking sub-skills among Egyptian first year university level intensive English course students?

3. What steps should be undertaken for designing the proposed program in the light of Internet- based collaborative tasks?

4. How far is the proposed program effective in developing Egyptian first year university level intensive English course students' overall EFL speaking?

5. How far is the proposed program effective in developing Egyptian first year university level intensive English course students' EFL speaking sub-skills?

\section{The study hypotheses}

\section{The study hypotheses were as follows:}

1. There is a statistically significant difference between the mean scores of the experimental group on the pre-test and the post- test in overall speaking performance in favour of the post- test.

2. There are statistically significant differences between the mean scores of the experimental group on the pre-test and the post- test in each speaking sub-skill in favour of the post- test.

\section{Objectives of the study}

\section{The main purposes of the current study were:}

1. Identifying the EFL speaking skills necessary for Egyptian first year university level intensive English course students.

2. Identifying appropriate techniques for designing a proposed program in the light of Internet- based collaborative tasks for developing the EFL speaking skills of first year university level intensive English course students. 
The Effectiveness of a Proposed Internet- Based Collaborative Tasks Program in Developing EFL Speaking Skills among Egyptian University Level Students

3. Constructing a proposed Internet- based collaborative tasks program to develop the necessary EFL speaking skills among first year university level intensive English course students.

4. Measuring the effectiveness of the proposed program in developing the necessary EFL speaking skills among first year university level intensive English course students.

\section{Delimitations of the study}

\section{This study was confined to:}

1. An intact intensive English course class of thirty students at October Modern Sciences \& Arts University in Giza governorate.

2. A specific duration for conducting the experiment (eleven weeks of the Spring 2018 Semester).

3. Eleven sessions for implementing the proposed program (The first session was an introductory one for two hours while the subsequent weekly three- hour ten sessions were dedicated for carrying out the program Internet- based collaborative tasks).

4. Developing only the six speaking sub-skills of (a) pronunciation, (b) grammar, (c) vocabulary, (d) fluency, (e) pragmatic competence as well as (f) ideas development and comprehensibility among the experimental group students.

\section{Definition of terms}

Internet- based collaborative tasks are real- life authentic meaningful activities that aim at achieving a real outcome using online written, audio and audio-visual sources. In these purposeful activities, students distribute and co-ordinate their work together while equally sharing the responsibility for their activity outcome (MacGregor, 1990; Nunan, 1992; Pantiz, 1999; Warschauer, Shetzer \& Meloni, 2000; Brown, 2007a).

These are defined operationally in this study as the study group students' ability to work in small groups of three to five using varied online sources to give oral presentations on the causes, effects and solutions of current societal problems, argue for or against the controversial ideas presented in the debate sessions and retell as well as comment on the program online digital stories.

Speaking is a means of communication among people that enables them to convey messages and express their viewpoints (Arung, 2016, p. 70). It is, also, a constructive interactive process that involves the reception, 
processing and exchange of information and perceptions (Burns \& Joyce 1997; Luoma, 2004).

It is defined operationally in this study as the experimental group students' ability to express themselves orally, fluently, coherently and adequately to convey meaning and achieve different communicative reallife functions. In other words, experimental group students are required to show mastery of the EFL speaking sub- skills of (a) pronunciation, (b) grammar, (c) vocabulary, (d) fluency, (e) pragmatic competence as well as (f) ideas development and comprehensibility.

\section{Variables of the study}

Independent variable: This refers to the treatment used in the study (the proposed program designed in the light of Internet- based collaborative tasks and implemented with the experimental group students).

Dependent variable: This refers to the experimental group students' performance in overall speaking and speaking sub- skills.

\section{Theoretical background}

\section{Definitions of speaking}

Speaking is "the process of building and sharing meaning through the use of verbal and non-verbal symbols, in a variety of contexts" (Chaney \& Burk, 1998, p. 13). Therefore, speaking form and content depend on the speech act participants, the purpose of the communication and context in which it takes place (Burns \& Joyce 1997; Luoma, 2004). Speaking is, also, defined as the use of verbal language to achieve human communication of thoughts and emotions (Howarth, 2001; Fulcher, 2003). It is usually used either for interactional or transactional purposes. This means that speakers communicate either to maintain social relationships or to exchange relevant information (Brown, 2007a).

\section{The nature of speaking}

While speaking, participants in the speech event are expected to co-operate; they are not supposed to mislead each other or hide relevant information from each other. In other words, they are expected to follow the four maxims of quality, quantity, relation and manner of Grice's Cooperative Principle. To abide by the quality maxim, they should only say what they believe to be true and what they have evidence for. Following the quantity maxim, they should give enough amount of information, neither too much nor too less than is required. They, also, need to give relevant responses and answers to other participants' questions. As for the manner maxim, they need to make sure that their speech is organized, clear and to the point (Yule, 1996 and 2010). 
In order to show that speakers are aware of the Co-operative Principle maxims, they usually use "cautious notes" or hedges like' As far as I know', 'To cut a long story short', 'Let me clarify myself' and 'I am not sure if this is relevant or not to your question'. However, in certain cases speakers seem to violate or flout the maxims of the Co-operative Principle in order to give implicatures that should be worked out by means of listeners' inference, which necessitates listeners' exertion of more mental effort to work out the speakers' intended non- literal meaning (Yule, 1996 and 2010).

There are varied types of spoken discourses. These include monologues, casual everyday conversations, discussions, formal speeches, interviews, lectures, oral presentations and debates (Scarcella \& Oxford, 1992; Ur, 1996; Brown, 2007a). Everyday conversations are usually characterized by pauses, hesitations, overlaps, backchannels, repetitions, false starts, the use of fillers, less specialized vocabulary and simpler grammatical structures than those used in written discourses (Carter \& McCarthy, 1995; Nunan, 2004; Brown, 2007a).

As for formal speeches and lectures, they are often more organized by following a clear structure; they are usually more coherent and cohesive. In addition, they have more specialized vocabulary and longer more complex grammatical structures than casual conversations have (Nunan, 1989; Carter and McCarthy, 1997; Osborn, Osborn, \& Osborn, 2009). In addition, in casual conversations, there should be smooth turn taking between the speech act participants; if one participant attempts to hold the floor, it shows that there is a sense of competition and that the conversation is not flowing as smoothly as it should be. On the other hand, in lectures and formal speeches, it is more customary and acceptable for the lecturer or the speaker to hold the floor (Yule, 1996).

One major difference between casual everyday conversations on one end and formal speeches or lectures on the other end is the fact that everyday life conversations are more spontaneous and are carried out with little, if any, prior preparation (Nunan, 1989; Carter and McCarthy, 1997). On the other hand, ample opportunities for proper preparation make formal speeches and lectures well- structured, to the point and more similar to written discourses than to casual conversations (Osborn, Osborn, \& Osborn, 2009).

\section{Speaking sub-skills}

As a complex skill, speaking has a number of sub-skills that EFL learners need to develop to foster their overall speaking performance. A synthesis of these sub- skills revealed that several scholars highlight 
linguistic competence, pragmatic competence, discourse competence, strategic competence and fluency as main components of speaking proficiency (Canale \& Swain, 1980; Bachman, 1990; Nunan, 1991; Scarcella \& Oxford, 1992; Scrivener, 2005; Brown, 2007a; Nation \& Newton, 2009). Linguistic competence involves the proper usage of a range of vocabulary and grammatical structures to express ideas as well as the accurate pronunciation of sounds, words and sentences following the rules of English stress, rhythm and intonation patterns (Carter \& Nunan, 2004).

As for pragmatic competence, it refers to the speaker's ability to effectively and adequately express a wide range of functions to achieve communicative goals (Cornbleet \& Carter, 2001). Examples of these functions include inviting, apologizing, ordering, offering, narrating, arguing for or against a certain idea, agreeing, disagreeing, suggesting and informing (Chamot \& O'Malley, 1994; Yule, 1996).

Discourse competence entails that speakers' utterances are coherent and cohesive (Canale \& Swain, 1980; Scarcella \& Oxford, 1992; Celce Murcia , 2001). Coherence means that parts of the spoken discourse stick together by means of a clear method of ideas development and with the help of adequate coherence markers to ensure the logical smooth flow of ideas. As for cohesion, it refers to sentences connectivity within the speakers' utterance. Such connectivity is achieved through the use of cohesive devices like reference, substitution, conjunctions and ellipsis. Furthermore, discourse competence means that speakers can manage conversations and interact effectively to keep the conversation going (Scarcella \& Oxford, 1992).

Strategic competence entails speakers' ability to effectively use conversation management and compensatory strategies. Conversation management strategies enable speakers to start a talk and to respond to other participants on a wide range of topics. Compensatory strategies mean that speakers should be also able to use gestures, miming, paraphrasing or circumlocution to get their message across in case they lack the adequate vocabulary knowledge. In addition, when interlocutors encounter a problem in the course of the speech act, they should be able to interrupt politely to request for repetition and clarification to avoid any possible misunderstanding (Canale \& Swain, 1980; Canale,1983; Canale, 1984, Scarcella \& Oxford, 1992; Hedge, 2000; Xu, 2016).

Fluency refers to learners' ability to speak confidently, effortlessly and smoothly at a normal speech rate that is closer to that of a native speaker (Richards, 2006; Brown, 2007a, Nation \& Newton, 2009). As for sociolinguistic competence, it highlights speakers' ability to select the utterance form that is considered appropriate within a language 
community in a particular communicative context taking into consideration factors like the level of formality, proper register selection as well as participants' age, background and relationships to one another (Canale \& Swain, 1980; Savingon, 1983; Tarone \& Yule, 1989; Brown, 2007a).

\section{Internet- based collaborative learning}

Collaboration is gaining more emphasis nowadays; it "has become a twenty- first century trend" (Laal \& Laal, 2012, p. 491). There is an increasing societal need for individuals who are able to work together on varied issues that socially and emotionally challenge them (Austin, 2000). This, in turn, necessitates that these individuals should critically listen to varied view points, share their ideas and defend them (Laal, 2012).

Following the increasing demand for learners' team- building skills, collaborative learning is a teaching approach based on social constructivism where groups of learners work together to solve problems, carry out tasks or create products (MacGregor, 1990; Nunan, 1992; Smith \& MacGregor, 1992; Laal \& Laal, 2012). It is grounded in the idea that learning is a social act by nature where participants talk among themselves. Hence, through this active talk and interaction, learning takes place (Gerlach, 1994). This interactive nature of collaborative learning enhances EFL university level learners' speaking skills and fluency as proved by the studies of Pattenpitchet (2011) and Gamba (2013).

There are five main characteristics that distinguish a collaborative learning environment. These are learners' (1) interdependence, (2) interaction, (3) accountability and personal responsibility, (4) social skills of leadership, decision - making and conflict management and (5) selfevaluation of group work quality (Johnson, Johnson, Stanne \& Garibaldi, 1990). Furthermore, collaborative learning is different from co-operative learning in a number of aspects. While co-operation is a an interactional structure designed to facilitate learners' goal achievement through their group work, collaboration is an interactional philosophy and a personal lifestyle that encourages individuals' increased sense of responsibility towards their actions and respect for peers' skills and contributions (Pantiz, 1999).

In a co-operative learning classroom, the teacher maintains complete control of the class even though learners work in groups to attain a certain goal. On the other hand, in collaborative learning, groups assume almost total responsibility for answering questions, completing tasks and achieving goals (Pantiz, 1999); they determine whether they have sufficient information to answer relevant questions, and if not, they 


\section{Ebtihal A. Helal, Ph.D.}

are responsible for finding other sources whether print or online sources, videos or audios. The teacher's role in a collaborative learning model is that of a facilitator and a guide of the students who "develop a very strong [sense of] ownership" (Laal \& Laal, 2012, p. 494). Thus, collaborative learning is more student- centered. It is based upon building consensus (Roseli, 2016) among group members who are equally accountable for the quality of their final product after task completion.

In the current technological age, the use of the Internet has become an effective tool that should be properly integrated in the EFL classroom (Warschauer, Shetzer \& Meloni, 2000). Internet- based collaborative learning uses the Internet as a means of achieving the learning goal or completing the task at hand (Brown, 2007a). It enhances EFL learners' motivation and positive attitude, thus resulting in better learning effects (Choi, 2008). Furthermore, it develops EFL learners' computer skills and ability to critically evaluate the credibility of the huge amount of sources available on the Internet (Warschauer, Shetzer \& Meloni, 2000). It, also, gives them a genuine reason for interaction inside and outside of the EFL classroom (Choi, 2008).

\section{— Task- Based Instruction}

Task- based instruction is an approach to EFL learning/ teaching that integrates language skills through tasks (goal- oriented activities) in which learners use the language to achieve a real outcome (Nunan, 1989 and 1991; Willis, 1996, p.53; Ellis, 2003; Skehan, 2003). Furthermore, it is "an analytical approach to language pedagogy... whereby students are exposed to holistic chunks of language that they can analyse themselves" (Ducker, 2012, p. 3). Nunan (2004) identifies a number of principles that should be taken into account while designing and implementing a taskbased curriculum. These are (i) offering students enough guidance or scaffolding, (ii) helping them acquire the language through its active use, (iii) integrating form and function and (iv) building tasks upon each other (task dependency).

In that sense, tasks are activities that focus on meaning; they are related to the real world and are evaluated on the basis of their outcome (Foster \& Sekhan, 1996). They require "learners to use the language...to attain an objective" (Bygate, Skehan \& Swain, 2001, p.11). In addition, tasks should be motivating and arouse EFL learners' interest (Willis \& Willis, 2007, p.12- 14). Besides, Long (1989) classifies tasks into target and pedagogic tasks; target tasks refer to "what the learner will eventually do in English" whereas "pedagogic tasks" are "activities worked on in the classroom to approximate the target tasks" (p.6). As for Ellis (2003), he 
distinguishes between three types of tasks: production tasks, comprehension tasks and consciousness raising tasks. While production tasks elicit learners' output, comprehension tasks encourage EFL learners to process the linguistic input more efficiently. Consciousness- raising tasks focus on a specific linguistic feature such as a certain grammatical pattern, relevant vocabulary or a pronunciation aspect to enhance L2 learners' linguistic proficiency.

Willis (1996) suggests a pedagogic framework of Task-Based Instruction that divides a task-based lesson plan into three phases. These are the pre-task phase, the task cycle and the post- task phase. The pretask stage aims at preparing the students for the task at hand through introducing students to the lesson topic and task, exposing students to similar tasks done by L2 learners and using consciousness-raising activities. In this stage, students are exposed to real language through tape recordings, audio CDs, videos or podcasts of English language speakers completing the same tasks. During the task cycle, students plan for the task; they draft, rehearse, do the task with the teacher's guidance and report it. As for the post- task phase, they reflect upon the task, selfevaluate their performance and focus more on the language used in the task through further analysis and practice.

There is a wide range of speaking tasks such as role plays, storytelling, debating and giving oral presentations (Ur, 1996; Nunan, 2004; Brown, 2007a; Kirkgöz, 2011; Alasmari \& Ahmed, 2013; Kuśnierek, 2015). "Task- based instruction is considered to be potentially suitable for learners of all ages" (Kirkgöz, 2011, p. 2). Not only did several studies prove the effectiveness of Task- Based Instruction in developing EFL university level learners' speaking skills but also quite a good number of studies affirmed its effectiveness in developing EFL learners' speaking proficiency in varied contexts with other age groups as in the studies of Gutiérrez (2005), Torky (2006), Farahani \& Nejad (2009), Murad (2009), Promruang (2012), Hasan (2014), Akbulut (2014), Munirah \& Mushin (2015), Cardona (2016), Fonseca-Martínez (2016), Albino (2017) and Taiwari and Mani (2017).

\section{Debates}

Debating is a speaking task that encourages EFL learners to defend their stances, refute counter arguments and provide logical reasons through conducting research (Shuster \& Meany, 2005; Morse, 2011; Alasmari \& Ahmed, 2013). Therefore, if it is adequately and sufficiently practised in the EFL classroom, it will make learners more confident users of the target language in varied settings (Morse, 2011; Alasmari \& 
Ahmed, 2013; Burek \& Losos, 2014; Coşkun, 2016). In a study conducted on Japanese students, Fukuda (2003) found that before practising debating only $30.8 \%$ of the students were not afraid to express their viewpoints. After the debate practice, this percentage rose to $56.7 \%$. In addition, in Stewart's (2003) study, it was found that $75 \%$ of demotivated students considered a debate as their preferred classroom activity.

Debates offer EFL teachers the chance to combine the skills of speaking and listening in a meaningful context (Alasmari \& Ahmed, 2013; Burek \& Losos, 2014). In their studies, Davidson (1995) and Krieger (2005) found that with debate practice, many EFL students were better able to express and support their ideas, and they could more quickly recognize the fallacies and inconsistencies in each other's arguments. A debate is, therefore, "an important educational tool for learning analytic thinking skills and for forcing self- conscious reflection on the validity of one's ideas." (Nisbett, 2003, p. 210).

Debates develop EFL learners' speaking, critical thinking ability and problem solving skills (Ebada, 2009; Coşkun, 2016). When EFL students debate, all the four language skills are enhanced (Morse, 2011). Regular practice of debate can enhance EFL learners' fluency, vocabulary and pronunciation (Alasmari \& Ahmed, 2013). Therefore, studies conducted by Baso (2016) and Arung (2016) indicated the positive impact of debates on EFL learners' speaking skills. Debates were also found to promote Egyptian EFL university level learners' vocabulary and decision making skill in Ahmed's (2018) study.

In a collaborative debate context, EFL teachers should form debate teams of three to five students in each team and select topics for them. Teams' positions to the topics can be given through lottery. Debaters should be allowed enough preparation time of thirty to forty- five minutes before the debating starts. When the debate starts, the EFL teacher acts as a moderator; the rest of the class plays the role of audience who will decide on the winning team at the end of the debate. Students within each team (whether the affirmative or the negative team) must divide the points among themselves, follow team strategies and use facts, figures, statistics and examples whenever possible to logically convince the audience and rebut the other team's arguments (Shuster \& Meany, 2005; Alasmari \& Ahmed, 2013; Burek, \& Losos, 2014 ).

\section{— Digital storytelling}

Storytelling is an effective way to foster the EFL speaking skill as it makes language learning more fun, motivating and enjoyable (Kayi, 
2006). Digital storytelling "combines the art of telling stories with a mixture of digital media, including text, pictures, recorded audio narration, music and video" ( Robin, 2016, p.18). These multimedia elements are blended with the help of computer software like "Movie Maker for Windows, Apple iMovie for Mac... or the web-based tool of Wevideo" (Robin, 2016, p.25- 26) to tell a story that reflects a specific view point of its author.

Any digital story has seven elements. These are the author's perspective or view point, a question to be answered at the end of the story, an emotional content, the storyteller's voice, a soundtrack, economy and pacing. Economy refers to conveying the author's message as briefly as possible without annoying the viewer with too many details while pacing is related to the speed of the story progress (Educational Uses of Digital Storytelling, 2019). Digital stories are usually uploaded on the Internet where they may be viewed through different web browsers. There are varied types of digital stories; among them are the three major types of (1) narratives, (2) documentaries and (3) stories that aim at informing or instructing viewers on certain notions or practices (Robin, 2006). Most digital stories last from two to ten minutes, and they can be watched on computers or other modern technological devices that are capable of playing video files (Robin, 2016, p.18).

Digital stories are a powerful technological instructional means in the twenty first century (Robin, 2008). For instance, they proved to be effective in developing EFL learners' listening comprehension in Verdugo's and Belmonte's (2007) study, vocabulary in Abdul-Ameer's study (2014) as well EFL reading and writing skills in Rahimi's and Yadollahi's (2017) study. They were, also, found to have a positive impact on Indonisian EFL learners' speaking, motivation and digital literacy in a study conducted by Wahyuni \& Sarosa (2017); furthermore, in Wahyuni's \& Sarosa's (2017) study, it was found that working on digital storytelling projects enhanced Indonesian EFL learners' speaking sub-skills of grammar, pronunciation and vocabulary.

Digital storytelling was proved to be an effective means of meeting EFL Chinese learners' varied needs in Dong's (2015) study. It, also, helped develop EFL Romanian learners' speaking and writing skills in a study conducted by Pop (2012). In addition, Pop's (2012) study concluded that digital storytelling fostered EFL Romanian learners' motivation, involvement and interest in learning English. Moreover, in their study, Tahriri, Tous \& MovahedFar (2015) proved that digital storytelling 
improved EFL learners' speaking and listening skills and fostered their motivation.

As for Husband (2014), he maintains that digital storytelling equips prospective EFL teachers with essential skills for the $21^{\text {st }}$. century. It is a promising tool that EFL teachers can use to foster EFL learners' speaking, reading, grammar, vocabulary and writing skills (Christiansen \& Koelzer, 2016). It is a meaningful instructional tool that integrates information technology in the English language teaching domain (Røkenes, 2016).

Digital storytelling fostered EFL Iranian undergraduate students' oral proficiency in a study conducted by Razmi, Pourali \& Nozad (2014). Besides, in an experimental study that was conducted throughout an academic year, it was found that digital storytelling fostered learners' achievement, critical thinking and motivation (Yang \& Wu, 2012). Moreover, digital stories developed Egyptian preparatory stage EFL learners' writing and reflective thinking in a study conducted by Seifeddin, Ahmed and Ebriahim (2015). It also enhanced Algerian EFL teenage school students' creative writing skills in Benmedjedel 's (2017) study.

In addition, based on their study, Smeda, Dakich and Sharda (2014) concluded that digital storytelling is an innovative instructional approach that creates a meaningful engaging constructivist learning environment. As for Tiba, Condy, Chigona \& Tunjera (2015), they found in their qualitative research that trainee teachers in South Africa viewed digital storytelling as a useful means "to (i) motivate and engage the students, (ii) promote voice/ self- expression, and (iii) promote collaborative learning as well as the acquisition of multiple skills" (p.285). Furthermore, digital storytelling was proved to be effective in developing EFL speaking skills among Egyptian EFL primary stage pupils in Haroun's (2012) and Mostafa's (2018) studies.

\section{Oral presentations}

Oral presentations are real- life tasks that encourage EFL learners to use both linguistic and paralinguistic features to convey meaning and express their viewpoints. They can be either controlled, guided or free to suit EFL students' varied linguistic proficiency levels (Al-Issa \& ALQubtan, 2010). Controlled presentations are suitable for elementary level EFL learners while guided ones are more convenient for lower intermediate level learners. As for free oral presentations, they are more adequate for upper- intermediate and advanced level learners (Al-Issa \& AL-Qubtan, 2010; Derakhshan, Tahery \& Mirarab , 2015).

Oral presentations are student- centered activities that can foster EFL learners' oral proficiency (Celce-Murcia, 2001; King, 2002; Miles, 2009); they offer EFL learners a genuine reason for communication, thus 
enhancing both their speaking accuracy and fluency as proved in Yahay's \& Kheirzadeh's (2015) study. In addition, different studies have proved the positive impact of oral presentations on enhancing EFL learners' speaking skill such as the studies of Mazdayasna (2012), Sotoudehnama \& Hashamdar (2016) and Farabi, Hassanvand \& Gorjian (2017).

Among the advantages of practising oral presentations in EFL classrooms are (a) integrating language skills, (b) reducing speech anxiety, (c) enhancing learners' self- confidence, motivation, autonomy, decision- making, speaking proficiency and future employability opportunities, (d) preparing learners for the real world and (e) fostering their digital literacy skills (Kingen, 2002; Hovane, 2009; Al-Issa \& ALQubtan, 2010; Ben Alahem, 2013; Brooks \& Wilson, 2014; Živković, 2014).

According to Ming (2005) and Brooks \& Wilson (2014), a group presentation class should start with the EFL teacher setting clear guidelines for the preparation, presentation and reflection stages. Students should be allowed the freedom to choose their presentation topics. Then, they should be encouraged to search for interesting ideas for their presentations using print and online sources; they can incorporate written, visual as well as audio- visual elements to enrich the quality of their oral presentations. Students should, also, organize the structure of their presentations to have an adequate introduction, enough main ideas and supporting details in the body and a sound conclusion that summarizes the main points and rounds off the talk. Images, figures, charts and videos included in a PowerPoint presentation make the audience more engaged and arouse their interest (Brown, 2007a).

When members of the presentation group divide their work properly and equally and rehearse well, their presentation clearly reflects adequate group dynamics and thorough knowledge of the presentation topic. Group presentations help EFL learners appreciate the value of collaborative team work (Al-Issa \& AL-Qubtan, 2010). A good presentation is a thought- provoking one that encourages the audience's comments and questions. After giving presentations, there should be ample time for students' reflections on their performance to identify their strengths, weaknesses and areas for future improvement (Ming, 2005; Brooks \& Wilson, 2014).

For a good oral presentation, Živković (2014) advises oral presenters to (1) involve their audience, (2) practise and rehearse enough before presenting, (3) stay positive, (4) speak clearly, (5) avoid reading 
from notes or slides, (6) use visual and/ or audio- visual aids to maintain audience interest, (7) use humor to add life to the presentation, (8) maintain eye contact and (9) respond politely to the audience's comments and inquiries at the end of the presentation. While giving oral multimedia PowerPoint presentations is a main form of computer- assisted language learning (CALL), it is important to always be ready with plan B or a back-up plan in case any technical problem arises during the presentation (Brown, 2007a).

\section{Related studies}

This section is divided into three sub-sections. These are as follows:

I. Studies examining the role of Task- Based Instruction in developing EFL speaking skills among university level learners

Kirkgöz (2011) conducted a study on a group of twenty- eight first year Turkish student teachers of English at the Faculty of Education, Çukurova University. The study participants had a speaking course where face- to- face Task- Based Instruction was blended with the use of technology in the form of recording their speaking performance with the help of video cameras. The study followed the mixed method where quantitative data were collected using a pre-/post- speaking test and qualitative data were collected through informal interviews with the students, analysis of students' speaking performance in video-recorded tasks and end- of academic year course evaluation survey. The study results revealed that the implemented treatment fostered the student teachers' speaking proficiency, especially in terms of expanding their vocabulary and improving their linguistic competence. Through interviews and course evaluation survey, it became evident that the course fostered the participants' self- confidence and motivation to speak using the target language; it, also, helped them to overcome their anxiety and shyness to speak in front of others. As a result, it was recommended to replicate the study on a wider scale and use the proposed treatment to develop other language skills as well.

Ismaili (2013) investigated the impact of task- based learning on developing EFL university level students' speaking skills. In addition, the study examined teachers' and students' attitudes towards Task- Based Instruction. The study participants were sixty undergraduate students at South East European University (SEEU). Their age ranged from eighteen to twenty- five years old, and their EFL proficiency level ranged from pre-intermediate to intermediate levels. The study sample was randomly assigned into two groups: the control and experimental groups. While the experimental group practised speaking according to Task- Based 
Instruction, the control group received regular instruction. The treatment took place over a period of eight weeks during the Winter 2012 Semester. The study tools included a pre-/ post- speaking test, a speaking analytic rubric and a questionnaire. Results of the pre-/post- speaking test revealed significant gains in the experimental group students' speaking proficiency as compared to the control group students. Teachers and students had positive attitudes towards Task- Based Instruction. It was found that this approach motivated the participants, encouraged learners to help and support each other and enhanced their autonomous learning. Based on the study results, it was recommended to adopt 'closed' speaking tasks with pre-intermediate and intermediate students whereas 'open' creative tasks were seen as more appropriate for EFL learners with higher linguistic proficiency levels.

Ho and Long (2014) examined the effect of Task- Based Instruction on developing Vietnamese first year English major trainee teachers' speaking skills. They, also, explored the students' attitudes towards Task- Based Instruction. The study participants consisted of twenty-three students who followed that task- based instructional plan to develop their oral performance over a period of fifteen weeks. The study tools included a pre-/ post- speaking test, a students' questionnaire and a students' observation note. The study results revealed the positive effect of Task-Based Instruction on the students' oral proficiency level. It was found that adopting this approach had substantially enhanced the students' fluency and self- confidence. The questionnaire results revealed that prior to the implementation of Task-Based Instruction, students encountered speaking difficulties. These difficulties were attributed to the lack of enough opportunities to practise speaking, their earlier low selfconfidence as well as their need to be equipped with the necessary vocabulary and grammatical patterns to speak confidently. After the treatment, students maintained that they liked Task-Based Instruction and viewed it as an adequate approach to develop their speaking skill. Moreover, participants confirmed that Task-Based Instruction made them feel more comfortable and sure of their abilities during oral communication.

Ji (2014) investigated the impact of Task- Based Instruction on developing public speaking skills. The study participants were thirty- four Chinese university level students who gave two speeches in a public speaking course. The study used questionnaires completed by the participants after the first and second public speaking to identify the effect of Task- Based Instruction on the participants' speaking accuracy 


\section{Ebtihal A. Helal, Ph.D.}

and fluency. Questionnaires indicated relevant improvement in the study participants' second public speech as compared to their first individual public speech. Speeches delivered by two of the participants were comprehensively analyzed, and they provided evidence for substantial phonological development. Therefore, it was concluded that Task- Based Instruction can foster EFL learners' speaking by encouraging them to take the initiative and pursue EFL learning opportunities inside as well as outside the classroom.

Mohammadipour \& Rashid (2015) studied the impact of a suggested Task- Based Instruction program designed in the light of the Cognitive Approach on developing ESL speaking skills among seventytwo first- year Malaysian undergraduate students. The study followed the quasi- experimental method. The experimental group students were taught according to the proposed program for three months while the control group students received regular instruction. The study used a pre-/ post- speaking test to measure the effectiveness of the suggested program. Results of the post- test administration revealed that the program had a positive impact on the experimental group students' overall speaking skill. Therefore, it was recommended to adopt Task- Based Instruction to foster ESL speaking among university level learners.

Hamouda (2016) examined the effect of Task- Based Instruction on fostering EFL speaking skills among Saudi English language and translation department students at Qassim University. The study also aimed at investigating the students' perceptions of Task- Based Instruction and its effectiveness in developing their speaking skills. To achieve the study aim, sixty students were randomly assigned into the control and experimental groups with thirty students in each group. While the experimental group students practised speaking in six instructional units according to Task- Based Instruction, the control group students practised speaking in the same six units according to regular instruction. The study tools included a pre-/ post- speaking test, a students' questionnaire and semi-structured interviews. Results of the study indicated that the experimental group students achieved tangible progress in their speaking proficiency level as compared to the control group students. Analysis of the questionnaire and interviews results indicated that the majority of the experimental group students enjoyed Task- Based Instruction and believed that it helped foster their speaking skills. Furthermore, it was concluded that Task- Based Instruction increased the experimental group students' participation, reduced their anxiety level and fostered their self- confidence as well as risk- taking ability to speak and express themselves. 
In their study, Sariçoban \& Karakurt (2016) explored the impact of Task- Based Instruction on EFL university level Turkish learners' listening and speaking skills. The study was conducted during the 20142015 academic year. The study participants were 56 lower intermediate (B1) and intermediate level (B1+) non- specialist students who studied their EFL course at the School of Foreign Languages. The study participants were involved into sixteen task- based lessons to enhance both their listening and speaking skills. The study tools included a speaking and a listening pre-/ post- test as well as an interview. The interview was conducted with a random sample of 12 students with six students from both the B1 and B1+ groups. The study results indicated that Task- Based Instruction significantly fostered the listening and speaking skills of the intermediate level non- specialist students. As for the lower intermediate (B1) group, the treatment did not significantly enhance their listening skill but it had a significant impact on their speaking skill. Analysis of the interview responses revealed that nearly all the students enjoyed the task- based activities, and they all believed that these activities should be applied in the EFL classroom to foster learners' listening and speaking skills.

Córdoba Zúñiga (2016) conducted a qualitative case study to investigate the effect of Task- Based Instruction on integrating EFL language skills and promoting communicative competence among six public Colombian first year university level students. The study tools included a series of six interviews and six observations. The study treatment included six tasks that were implemented over a period of twenty hours. The study results indicated that, from the students' perception, Task- Based Instruction helped them practise using the target language in a meaningful integrated fashion. Also, observations revealed that Task- Based Instruction enhanced the learners' communicative competence. It, also, made them more self- aware and autonomous. Hence, to enhance the effectiveness of the Task- Based methodology, it was recommended to help EFL students set clear goals of their tasks in the pre- task phase and offer them informative positive feedback as well as varied follow- up exercises in the post- task phase.

Yousif (2017) examined the impact of Task- Based Instruction on enhancing the oral communication skills of Sudanese first year College of Languages students. The study, also, attempted to investigate EFL university level Sudanese instructors' perceptions concerning the methods adopted while developing learners' oral skills as well as the problems 
these instructors encounter while following Task- Based Instruction. To achieve the study aim, the researcher followed the mixed method where both qualitative and quantitative data were collected and analyzed. The study tools included a pre-/ post- oral communication skills test, a teacher's questionnaire and a students' observation card. The study sample consisted of thirty students who were randomly assigned into the control and experimental groups with fifteen students in each group. While the experimental group students were taught according to Task- Based Instruction, the control group students were taught according to the regular method. Results of the post- test administration indicated that the experimental group students outperformed the control group students in their oral communication skills, thus confirming the effectiveness of communicative tasks in developing EFL learners' oral skills. Furthermore, it was concluded that Task- Based Instruction had a positive influence on the experimental group students' fluency and accuracy. Analysis of the questionnaire results indicated that the EFL university level instructors preferred using communicative tasks to other methods or techniques while teaching oral skills to their students. The study confirmed the idea that Task- Based Instruction motivates EFL learners and enables them to express themselves more freely.

\section{Studies focusing on the role of collaborative learning in enhancing EFL university level students' speaking skills.}

Pattenpitchet (2011) investigated the effect of collaborative learning on enhancing EFL speaking skills among university level students in Thailand. The study participants consisted of thirty- five undergraduate students who were studying a fundamental English course at the University of Bangkok. Throughout the study treatment, the participants were involved in collaborative tasks that aimed at enhancing their speaking skills. The study tools included a pre- / post- speaking test, a questionnaire and semi-structured interviews. The participants were also required to write their reflections upon the completion of each instructional collaborative speaking task. Analysis of the study results indicated that collaborative speaking tasks fostered the participants' speaking proficiency level and resulted in their positive feedback.

Gamba (2013) conducted a study that aimed at fostering EFL Colombian learners' speaking fluency using collaborative self- directed tasks. The study participants were six Colombian EFL teachers and sixty pre- intermediate level EFL students. In this action research, each of the study teachers was asked to randomly select ten students from his/ her class. Fifty of the study students were EFL secondary stage students in public schools while ten students were enrolled in a private university. 
All the students who participated in this study had the same problem; i.e., they were unable to speak fluently using English as a foreign language. The study tools included a fluency measuring sheet, students' selfevaluation form, teachers' reflection and observation cards. In this study, students were given ten speaking tasks that necessitated their collaboration and self- direction. The treatment lasted for ten weeks, and in each week, students were given a different speaking task. Results of this study revealed the positive impact of the collaborative self- directed speaking tasks on enhancing the students' fluency. It was concluded that these collaborative tasks minimized the students' speaking anxiety and allowed them to share ideas.

III. Studies focusing on the role of digital storytelling, debates and oral presentations in fostering EFL university level learners' speaking skill

Baghdasaryan (2012) conducted a study to investigate the impact of digital storytelling on university level students' speaking skill. The study followed the quasi-experimental design. The study participants were twenty- four EFL students at the American University of Armenia; they were randomly assigned into the control and experimental groups with twelve students in each group. While the experimental group students used the digital storytelling technique to develop their speaking over a period of seven weeks, the control group students followed the traditional storytelling method. The study tools included a pre-/ postspeaking test, a questionnaire and semi- structured interviews. Results of the speaking test post- administration indicated that the experimental group students outperformed the control group students. Based on the study findings, it was concluded that digital storytelling fostered the experimental group students' speaking skills and positive attitudes.

Somdee (2012) examined the effect of digital storytelling on developing the speaking skills of Thai undergraduate students. The study participants were fifty students studying an English language compulsory course at Suranaree University of Technology. The study followed the one experimental group pre-test/ post-test design. Participants were encouraged to create and share their own digital stories using a digital storytelling website designed by the researchers. The treatment lasted for ten weeks. Participants' speaking skill was measured prior to and after the treatment. Twenty students' perceptions of the digital story website were investigated using semi- structured interviews. Results indicated that digital storytelling fostered the participants' oral proficiency. In addition, 


\section{Ebtihal A. Helal, Ph.D.}

students liked the digital story website, and believed that it helped them develop their speaking skill while maintaining their interest and engagement.

Dekdouk (2013) conducted a study to examine Algerian second year English department students' and their teacher's perceptions with regard to the role of oral presentations in enhancing learners' communicative competence. The study tools included a students' questionnaire and a teacher's interview. Results of the students' questionnaire revealed that most of the students believed that oral presentations fostered their grammar, pronunciation and vocabulary skills. $65 \%$ of the students believed that oral presentations taught them how to start, develop and end their spoken discourses. In addition, 56.3\% of the students maintained that oral presentations enhanced their fluency, especially when they were well- prepared for the presentations and had accompanying written support while delivering the presentation. Results of the teacher's interview revealed that she frequently used oral presentations in class to foster her students' communicative competence. Furthermore, the teacher maintained that after giving the oral presentations, students were encouraged to participate in a debate to increase their classroom oral interaction. Based on the study findings, it was concluded that oral presentations can substantially develop EFL learners' linguistic competence, strategic competence, discourse competence, pragmatic competence and fluency.

Ben Alahem (2013) investigated Algerian TEFL students' and instructors' perceptions concerning the role of oral presentations in reducing speech anxiety. To achieve this aim, the study made use of a students' questionnaire and teachers' structured interviews. The study sample consisted of eighty- seven second year TEFL students and six teachers at Mohamed Khieder University in Biskra. The students' age ranged from nineteen to thirty- five years old, and they were sixteen males and seventy one females. Analysis of the students' questionnaire revealed that $52.9 \%$ of them sometimes felt stressed when they had to speak in public without enough preparation or practice. In addition, $40 \%$ of the students preferred oral presentations as a means of fostering their speaking skill to discussions, role plays and storytelling. $43 \%$ of the participants preferred free to guided or controlled oral presentations as these free presentations enabled them to express themselves better. In their interviews, teachers believed that high anxiety levels and low selfesteem can hinder the development of effective EFL speaking skills. $83.3 \%$ of the teachers believed that oral presentations can help their students develop their speaking skills, and $66.7 \%$ expressed their belief that these presentations can substantially help reduce EFL learners' 
speech anxiety. Based on the study findings, it was recommended to conduct further experimental studies to measure the effectiveness of oral presentations in developing EFL learners' speaking skills and reducing their anxiety levels.

Kim (2014) investigated the impact of digital storytelling autonomous learning experience on enhancing ESL oral proficiency level of five participants enrolled in the City college of San Francisco. Four of the study participants were immigrants to the US while one participant was an international student who was studying in the US for a year and a half. Their age ranged from twenty to thirty two years old. Their ESL linguistic proficiency level ranged from upper- intermediate to advanced level. Participants were encouraged to record their own digital stories using the two self- study resources of Vocaroo and vozMe. They were also asked to use their VoiceThread accounts to listen to and record their digital stories. This experimental study used both the qualitative and quantitative methods. Students' oral proficiency level was measured prior to and after the treatment. In addition, three questionnaires investigated the participants' attitude towards the autonomous learning experience of digital storytelling. The study results revealed that digital storytelling enhanced the participants' speaking skill and boosted their selfconfidence. It was, also, concluded that digital storytelling offered a learner- centred environment that fostered the participants' autonomy.

Rokni \& Qarajeh (2014) compared the effectiveness of traditional storytelling versus digital storytelling in fostering EFL Iranian translation students' speaking skill. The study participants were forty students at Payam Noor University. Their age ranged from nineteen to twenty five years old, and they were all intermediate level EFL learners according to the Oxford Placement Test administered at the beginning of the study. Participants were randomly assigned into the experimental and control groups. While the experimental group students were encouraged to create their own digital stories in eight sessions, the control group students used the traditional storytelling method. In addition to Oxford Placement Test, the study tools included a Pre-/ Post- TOEFL speaking test and a questionnaire. The study results indicated that the experimental group outperformed the control group in the post- administration of the TOEFL speaking test. This significant difference was attributed to the digital storytelling treatment. Questionnaire results indicated that experimental group students believed that digital storytelling motivated them and promoted their speaking performance. 
Pardo (2014) examined the impact of digital storytelling on enhancing the speaking \& writing skills of EFL undergraduate Faculty of Education third year students in Spain. The study participants were twenty one students whose age ranged from eighteen to thirty- five years old. They were intermediate level students. In this case study, participants were involved in a digital story creation project using Photostory 3 software. Participants' perceptions of the digital story project were obtained with the help of a questionnaire designed by the researcher for that purpose. The study results indicated that the digital story project improved the participants' writing and speaking skills. This was evident as they made fewer grammatical errors and improved their pronunciation. However, it was indicated that participants needed more training in pronunciation and intonation. Questionnaire results revealed the students' appreciation of the innovative techniques included in the digital storytelling project. Furthermore, it was concluded that such a project improved the participants' organization, problem solving and interpersonal skills.

Sabbah (2015) examined the effectiveness of debates in enhancing Palestinian university level English majors' speaking skill. The study participants were twenty students at the University of Palestine in Gaza Strip. The study followed the quasi-experimental design. The study tools included a pre-/ post- speaking test and a teacher's guide to help EFL teachers implement the debate strategy in their classes. The participants practised debating on real life topics throughout the first semester of the academic year 2014- 2015. Comparing the pre-/post- speaking test results revealed that the debates used in this study had a positive impact on the participants' speaking sub- skills of grammar, vocabulary and pronunciation. Therefore, it was recommended to use debates in EFL university level classes to foster learners' speaking skill.

Fauzan (2016) conducted a study in Indonesia to examine the impact of the debate technique and peer- assessment on fostering university level English Department students' speaking performance. This action research was conducted in two cycles. Each cycle consisted of four meetings. In the first three meetings, debates and peer assessments were employed and in the fourth meeting, the speaking test was administered. Results of the first cycle indicated that students' speaking average score has increased from sixty in the pre- test to sixty- nine in the first cycle and then to seventy- five at the end of the second cycle. Results of this study indicated that debates have helped the participants improve 
their speaking skill as well as fostered their self- confidence and creativity, thus enabling them to share and express ideas more freely.

Fauzi (2016) examined the impact of multi-media presentations on enhancing EFL speaking skills among Indonesian university level learners. In this action research, the study participants were thirty second year accounting students in a private university in Serang, Banten. The study was conducted in three cycles, and after each cycle, the students' speaking skills were assessed. The study tools included a questionnaire, an observation form, a presentation assessment form and an interview. As the participants practised multimedia presentation skills throughout the treatment, students' speaking skills improved at the end of the research third cycle, and they gave better presentations. However, it was highlighted that the students needed more practice in grammar and vocabulary to further promote their speaking skill. It was, also, indicated that multimedia presentations maintained students' interest as they effectively integrated images, videos, audios and texts in their presentations.

Abdelmageed \& El-Naggar (2018) investigated the effect of digital storytelling on enhancing EFL speaking among Egyptian university level learners at Zewail University of Science and Technology. This study, also, aimed at identifying the study participants' level of satisfaction with their digital storytelling experience. The study participants were eight first-year university students who were attending a remedial course during the Summer 2017 Semester. The study tools included a pre-/ postspeaking proficiency test, an analytic rubric for measuring the participants' speaking performance, semi- structured interviews and students' reflections written at the end of the treatment that lasted for five weeks. In this study, students were encouraged to write and share their own digital stories. Results of the study indicated that the digital storytelling experience fostered the participants' overall speaking proficiency. It was found that the treatment had a large effect size on the participants' fluency, grammar and comprehensibility sub- skills. It was also evident that the treatment had a medium effect size on the participants' pronunciation and vocabulary. In addition, students were satisfied with the digital storytelling experience, and they stated that it improved their self-confidence and enhanced their oral proficiency. However, it was highlighted that such findings should be taken with caution due to the small number of the participants and the treatment limited duration. Therefore, it was recommended to replicate the study 
using a larger sample size over a longer time frame to obtain more reliable results.

\section{Methodology of the study}

In conducting the current study, the researcher made use of both the Descriptive Method and the Quasi-experimental Method. The Descriptive Method was used while reviewing pertinent literature and specifying the speaking sub-skills necessary for EFL first year university level intensive English course students. It was also employed while identifying the general design of the proposed program, the speaking test and the speaking analytic rubric. The Quasi-experimental Method was used while conducting the experiment, administering the speaking test, analyzing the data and interpreting the results.

\section{The study participants}

A group of thirty first year intensive English course students at October Modern Sciences and Arts University were randomly selected in the Spring Semester of the academic year 2017-2018 . These represented the experimental group students that received the current study treatment. Students' age ranged from eighteen to twenty years old. They were students at the Faculties of Arts \& Design, Engineering, Management, Pharmacy and Computer Science. Prior to receiving the current treatment, the study participants were quite familiar with the use of Internet sources whether for academic or personal reasons. Therefore, they found no difficulty using the Internet to carry out the current program Internetbased collaborative tasks.

The experimental group students were taught by the researcher in a computer laboratory where there was direct access to the Internet and sufficient modern desktop devices for all the study participants throughout the implementation of the study experiment. When students seldom faced Internet connection problems, they were allowed to use their smart phones to log onto the Internet and carry out their collaborative speaking tasks.

\section{Research design}

The present study followed the quasi-experimental pre-test/ posttest one group design. 


\section{Tools of the study}

The present study made use of three main tools:

* A speaking skills checklist;

* A pre- /post- speaking test to measure the experimental group students' speaking skills; and

* An analytic rubric to score the experimental group students' oral performance on the pre- /post- speaking test.

These tools can be explained as follows:

\section{A. The speaking skills checklist}

This checklist was employed to determine the most important EFL speaking skills to be developed at the university level. To ensure the checklist validity, it was submitted to a panel of jury specialized in the field of EFL curricula and methods of teaching to determine (a) the degree of importance of each skill and (b) appropriateness of the skills suggested to Egyptian EFL first year university level intensive English course students. The jury consisted of seven staff members specialized in EFL curricula and teaching methods from different faculties of Education in Egypt. The panel of jury recommended that the current study should focus on the six previously highlighted speaking sub- skills as they were seen necessary and suitable for the target population of the current study.

\section{B. The pre-/ post- speaking test}

This test was constructed and administered on the experimental group by the researcher. It was used prior to the program implementation to assess the experimental group students' overall speaking performance and the specified six speaking sub- skills before starting the experiment. As a post-test, it was used to investigate the effectiveness of the proposed Internet- based collaborative tasks program in developing the experimental group students' overall speaking and speaking sub-skills.

To measure the test content validity, the first version of the test was given to a panel of jury consisting of six TEFL professors, assistant professors and lecturers. They were asked to evaluate the test as a whole in terms of the number of the test speaking tasks and their suitability to the linguistic level of EFL first year intensive English course students. 
The panel of jury indicated that test proved to be a valid one as it measured what it was intended to measure in most cases. To enhance the test validity, they added, modified and omitted some test tasks. The final form of the test followed the TOEFL IBT test pattern and consisted of six tasks that were divided into two main sections: independent and integrated speaking tasks. The first section consisted of four independent tasks whereas the second section had two integrated tasks.

The test was conducted in an interview format where the students were individually tested by the researcher who recorded their answers after getting their consent. The time allocated for the test was twenty-five to thirty minutes per learner, including giving them clear instructions on how to do the test. The test was marked out of twentyfour according to the analytic speaking rubric designed by the researcher.

\section{- Piloting the test}

Before administering the test on the study sample, it was piloted with the aim of timing the speaking test and determining its suitability. Therefore, fifteen students were selected for the pilot study. These students were randomly selected from one EFL first year intensive English course classes at Modern Sciences and Arts University. Results of the pilot study indicated that a period of twenty- five to thirty minutes would provide the students with ample time to comfortably complete the test tasks. The pilot study, also, indicated that the test tasks were suitable for the students as they had no difficulty understanding the test tasks although their oral performance exhibited obvious grammar, vocabulary, pronunciation and fluency problems. Students of the pilot study were excluded from the whole experiment.

In order to establish the reliability of the speaking test included in the current study, it was administered to a randomly selected group of fifteen students. After two weeks, the test was administered one more time to the same fifteen students. Then, the Pearson correlation coefficient between the test/ re-test results was calculated. The reliability coefficient was 0.81 , which is relatively high. Therefore, the test could be considered a reliable one for the purpose of the current study. 


\section{The speaking analytic rubric}

Students' speaking performance in the test was scored with the help an analytic rubric designed by the researcher. This rubric was reviewed by a jury of six TEFL and assessment specialists to ensure its objectivity, clarity and ability to adequately measure the students' speaking performance with regard to the specified six speaking sub-skills. The jury members' comments on the initial form of the rubric were taken into consideration while designing the final version of the rubric.

Using this rubric, a total of twenty- four marks was divided among the six speaking sub- skills of pronunciation, fluency, ideas development and comprehensibility, grammar, vocabulary and pragmatic competence. Each sub-skill had four performance levels ranging from very good to poor.

Following the final version of the rubric, experimental group students' performance on the pre-/ post- speaking test was assessed by the researcher and two other raters who were trained in using the rubric before assessing the experimental group students' oral performance. In addition, using Cronbach's Reliability Scale, inter-rater reliability was calculated. Cronbach's Alpha was 0.82 (significant at 0.01 level), indicating high internal consistency among the three raters as well as the reliability of their scoring. While calculating the experimental group students' scores on the pre-/ post- speaking test, raters' scores were pooled to get an average score for each speaking sub-skill.

\section{Treatment}

After the experimental group students completed their speaking pre- test, they received the current study treatment through a proposed Internet- based collaborative tasks program to develop their overall speaking performance and the specified speaking sub- skills. The following is a description of the steps the researcher went through to design this program.

\section{Aim of the program}

This program aimed at developing the speaking skills necessary for EFL first year university level intensive English course students. This was achieved through involving the experimental group students in Internetbased collaborative speaking tasks throughout the program implementation. 


\section{Ebtihal A. Helal, Ph.D.}

\section{Assumptions of the program}

\section{This program was based on the following assumptions:}

1. Speaking is a constructive interactive process of receiving, processing and exchanging information and viewpoints. It is a complex mental skill that entails the mastery of a number of subskills to ensure fluent effective communication of ideas.

2. Task- Based Instruction enables EFL teachers to engage learners in meaningful communicative activities that have a specific outcome and that are likely to be enacted in real life situations, thus motivating learners while developing their oral proficiency levels.

3. Collaborative learning tasks encourage EFL learners to work in groups, become more autonomous, co-ordinate and monitor their work to achieve a certain outcome while being equally accountable for the quality of their final outcome.

4. Using the Internet in collaborative tasks offers EFL learners a great opportunity to explore a huge number of varied written, audio and video sources, thus fostering their motivation and enthusiasm to participate effectively in those tasks and develop their linguistic proficiency levels.

5. The usual practice of debates and oral presentations can become more appealing to learners when varied online sources are used to collect enough ideas for those speaking tasks.

6. Digital storytelling combines the art of traditional storytelling with the engaging effect of soundtracks, images, narrator's voice, music and videos in a way that can attract EFL learners to watch, retell and comment on them.

7. When EFL students are required to work collaboratively using online sources for debating, giving multi-media oral presentations and retelling as well as commenting on digital stories, the classroom atmosphere becomes more studentcentered. In such a context, the EFL teacher's role is that of a guide, a scaffolder and a facilitator.

\section{Learning objectives of the program}

By the end of this program, students were expected to develop the six speaking sub- skills of ideas development and comprehensibility, fluency, pronunciation, grammar, vocabulary as well as pragmatic competence. 


\section{Content of the program}

The content of this program consisted of sixty- eight online videos, twenty one online digital stories and ten online podcasts that were carefully selected by the researcher to suit the EFL university level intensive English course students' linguistic proficiency level and help them develop the specified speaking sub-skills as they did the program speaking tasks. While selecting these videos and digital stories, the researcher made sure that they would be motivating, engaging and appealing to the students. It was, also, important to check their appropriateness to the learners' cultural values and background. The researcher made sure that the speakers' pronunciation in these videos was clear and accurate enough to help learners develop their pronunciation skills. Students accessed the online content of the current program on different websites including Youtube, BBC Learning English, the British Council Learn English Teens and Educational Uses of Digital Storytelling websites. This can be further explained in the following tables:

Table (1): Titles of the YouTube online videos watched in the introductory session

\begin{tabular}{|l|}
\hline Digital Storytelling: What It Is and What It Isn't \\
\hline Introduction to the Debate \\
\hline How to Prepare Your Oral Presentation \\
\hline
\end{tabular}

As shown in table (1), the above mentioned YouTube videos introduced the students to the three major Internet- based collaborative speaking tasks carried out throughout the program implementation.

Table (2): Titles of the BBC Learning English online pronunciation videos used in the consciousness- raising phase prior to speaking

\begin{tabular}{|c|c|}
\hline Session No. & Title of the pronunciation online videos \\
\hline 1. & Pronunciation of / $\boldsymbol{\theta} /$ and / Ø/ \\
\hline 2. & Pronunciation of / $\mathbf{t} \int /$ and $/ \mathbf{d} \mathbf{z} /$ \\
\hline 3. & Pronunciation of $/ \mathrm{s} /$ and $/ 3 /$ \\
\hline 4. & Pronunciation of / $\mathbf{p} /$ and / b/ \\
\hline 5. & Pronunciation of / f / , / v / and / $\mathbf{y} /$ \\
\hline 6. & Pronunciation of / eI /, / aI / and / o i / \\
\hline 7. & Pronunciation of /əu /, / av / \\
\hline 8. & Pronunciation of / $\boldsymbol{\Lambda} /, / \mathbf{p} /$ and / $\boldsymbol{u} /$ \\
\hline 9. & Pronunciation of / I o / and / eə / \\
\hline 10. & Pronunciation of / e /, / i / and / i: / \\
\hline
\end{tabular}

As indicated in table (2), the highlighted online pronunciation videos focused on the identified common pronunciation problems at the phoneme level to help the study group students overcome such problems 


\section{Ebtihal A. Helal, Ph.D.}

while speaking.

Table (3): Titles of the online grammar videos watched on the British Council Learn English Teens Website and used in the consciousnessraising phase prior to speaking

\begin{tabular}{|c|l|}
\hline $\begin{array}{l}\text { Session } \\
\text { No. }\end{array}$ & Title of the grammar online videos \\
\hline 1. & Present Perfect, Simple \& Continuous \\
\hline 2. & Past Simple Regular and Irregular Verbs \\
\hline 3. & Conjunctions \\
\hline 4. & Comparative and Superlatives \\
\hline 5. & Relative clauses \\
\hline 6. & Have to, Must and Should for Obligation and Advice \\
\hline 7. & Future Forms \\
\hline 8. & Passive Forms \\
\hline 9. & Conditionals \\
\hline 10. & Countable and Uncountable Nouns \\
\hline
\end{tabular}

As illustrated in table (3), the aforementioned online grammar videos focused on the grammatical aspects that were found quite problematic for the study group students to enhance their grammatical accuracy while speaking.

Table (4): Titles of the sample online debates, digital stories and oral presentations watched and analyzed prior to doing the speaking tasks

\begin{tabular}{|l|l|l|}
\hline $\begin{array}{l}\text { Session } \\
\text { No. }\end{array}$ & $\begin{array}{l}\text { Title of the speaking } \\
\text { sample }\end{array}$ & Source \\
\hline One & $\begin{array}{l}\text { A debate: I think cats make } \\
\text { better pets than dogs. }\end{array}$ & You Tube \\
\hline Two & $\begin{array}{l}\text { An online digital story: The } \\
\text { Birth of the Internet }\end{array}$ & $\begin{array}{l}\text { Educational Uses of Digital } \\
\text { Storytelling Website } \\
\text { University of Houston, } \\
\text { College of Education) }\end{array}$ \\
\hline Three & $\begin{array}{l}\text { Problem- Solution Group } \\
\text { Presentation on China's } \\
\text { Aging Population }\end{array}$ & You Tube \\
\hline Four & $\begin{array}{l}\text { Debate Topic: Should } \\
\text { schools require students to } \\
\text { wear a uniform? }\end{array}$ & \\
\hline
\end{tabular}


The Effectiveness of a Proposed Internet- Based Collaborative Tasks Program in Developing EFL Speaking Skills among Egyptian University Level Students

\begin{tabular}{|l|l|l|}
\hline Five & $\begin{array}{l}\text { An online digital story: } \\
\text { Decisions }\end{array}$ & $\begin{array}{l}\text { Educational Uses of Digital } \\
\text { Storytelling Website } \\
\text { University of Houston, } \\
\text { College of Education) }\end{array}$ \\
\hline Six & $\begin{array}{l}\text { Global Warming Group } \\
\text { Presentation }\end{array}$ & You Tube \\
\hline Seven & $\begin{array}{l}\text { Is Social Media Good or } \\
\text { Bad? }\end{array}$ & $\begin{array}{l}\text { Storytelling Website } \\
\text { University of } \\
\text { College of Education) }\end{array}$ \\
\hline Eight & $\begin{array}{l}\text { An online digital story: } \\
\text { Stress and Education }\end{array}$ \\
\hline Nen & Smoking Ban Debate & You Tube \\
\hline
\end{tabular}

As indicated in table (4), the sample online debates, digital stories and oral presentations helped familiarize the study group with the Internet- based collaborative tasks they carried out throughout the program sessions.

Table (5): Titles and sources of the digital stories watched $\&$ discussed during the collaborative speaking tasks

\begin{tabular}{|c|c|c|}
\hline $\begin{array}{l}\text { Sessi } \\
\text { on } \\
\text { No. }\end{array}$ & Digital Story Title & Source \\
\hline \multirow[t]{6}{*}{ Two } & 1. Run Your World & \multirow{6}{*}{$\begin{array}{l}\text { Educational Uses of } \\
\text { Digital Storytelling } \\
\text { Website ( University of } \\
\text { Houston, College of } \\
\text { Education) } \\
\text { /digitalstorytelling.coe.uh.e }\end{array}$} \\
\hline & $\begin{array}{l}\text { 2. Art as a Way of } \\
\text { Thinking }\end{array}$ & \\
\hline & 3. Music, Music, Music & \\
\hline & 4. How Low You Can Go & \\
\hline & 5. A Day Without Math & \\
\hline & 6. Technology in Medicine & \\
\hline
\end{tabular}


Ebtihal A. Helal, Ph.D.

\begin{tabular}{|c|c|c|}
\hline \multirow[t]{6}{*}{ Five } & 7. Famine and Emigration & \multirow[t]{2}{*}{$\mathrm{du} /$} \\
\hline & 8. Superman & \\
\hline & 9. It's All about You & \multirow[t]{10}{*}{ YouTube } \\
\hline & 10. Mother's love & \\
\hline & $\begin{array}{l}\text { 11. The Power of Being } \\
\text { Kind }\end{array}$ & \\
\hline & $\begin{array}{l}\text { 12. My Study Abroad- } \\
\text { Digital Story in Nagoya- } \\
\text { Japan }\end{array}$ & \\
\hline \multirow[t]{6}{*}{ Eight } & $\begin{array}{l}\text { 13. Teen Depression Digital } \\
\text { Story }\end{array}$ & \\
\hline & 14. Aly's Digital Story & \\
\hline & $\begin{array}{l}\text { 15. My Grandfather The } \\
\text { Mystery }\end{array}$ & \\
\hline & $\begin{array}{l}\text { 16.Digital Storytelling- } \\
\text { Friendship }\end{array}$ & \\
\hline & $\begin{array}{l}\text { 17. My Life and } \\
\text { Photography }\end{array}$ & \\
\hline & $\begin{array}{l}\text { 18.I Wish that Every Black } \\
\text { Kid Had My Dad }\end{array}$ & \\
\hline
\end{tabular}

As shown in table (5), the eighteen online digital stories watched and discussed in the current program covered a wide range of topics to enhance students' motivation, interest and involvement in the subsequent speaking tasks based on these digital stories.

Table (6): Titles of the YouTube online videos watched prior to debating accompanied by the subsequent collaborative debate topics

\begin{tabular}{|l|l|c|}
\hline $\begin{array}{l}\text { Sessio } \\
\text { n No. }\end{array}$ & $\begin{array}{l}\text { Title of the YouTube online } \\
\text { video watched prior to } \\
\text { debating }\end{array}$ & $\begin{array}{l}\text { The debate topic addressed in } \\
\text { collaborative groups }\end{array}$ \\
\hline \multirow{3}{*}{ One } & $\begin{array}{l}\text { Do Video Games Make You } \\
\text { Violent? }\end{array}$ & $\mathbf{1 .} \begin{array}{l}\text { Video games spread violence } \\
\text { among teenagers \& youth. }\end{array}$ \\
\cline { 2 - 4 } & Village Life vs. City Life & $\mathbf{2 .} \begin{array}{l}\text { Life in cities is much better than } \\
\text { life in towns or villages. }\end{array}$ \\
& $\begin{array}{l}\text { Why Animals Are Needed in } \\
\text { Research? }\end{array}$ & $\begin{array}{l}\text { 3. Scientists should be allowed to try } \\
\text { new medicines on animals. }\end{array}$ \\
\cline { 2 - 4 } $\begin{array}{l}\text { The Best Advice to Make } \\
\text { Someone Quit Smoking }\end{array}$ & $\begin{array}{l}\text { 4. Smokers should be legally } \\
\text { punished the same way like drug } \\
\text { addicts. }\end{array}$ \\
\hline
\end{tabular}


The Effectiveness of a Proposed Internet- Based Collaborative Tasks Program in Developing EFL Speaking Skills among Egyptian University Level Students

\begin{tabular}{|c|c|c|}
\hline & $\begin{array}{l}\text { How Close are we to Replacing } \\
\text { Humans with Robots? }\end{array}$ & $\begin{array}{l}\text { 5. Robots will soon replace humans } \\
\text { in many working environments. }\end{array}$ \\
\hline \multirow[t]{5}{*}{ Four } & Graffiti- Art or Vandalism? & 6. Graffiti: Art or vandalism? \\
\hline & $\begin{array}{l}\text { Will Genetic modification Keep } \\
\text { or Save humanity? }\end{array}$ & $\begin{array}{l}\text { 7. Genetic engineering is causing } \\
\text { more harm than good to mankind. }\end{array}$ \\
\hline & $\begin{array}{l}\text { Virtual Reality in Medicine- } \\
\text { New Opportunities for } \\
\text { Diagnostics and Surgical } \\
\text { Planning }\end{array}$ & $\begin{array}{l}\text { 8. Virtual reality is a promising } \\
\text { technological tool that can bring } \\
\text { about medical breakthrough. }\end{array}$ \\
\hline & How Recycling Works & $\begin{array}{l}\text { 9. Recycling has not solved the } \\
\text { problem of garbage and has } \\
\text { resulted in low- quality products. }\end{array}$ \\
\hline & $\begin{array}{l}\text { How Social Media Makes Us } \\
\text { Unsocial }\end{array}$ & $\begin{array}{l}\text { 10. Social networks are causing a lot } \\
\text { of troubles to the social } \\
\text { relationships they claim to } \\
\text { maintain. }\end{array}$ \\
\hline \multirow[t]{5}{*}{ Seven } & $\begin{array}{l}\text { Conventional Learning versus } \\
\text { Blended Learning }\end{array}$ & $\begin{array}{l}\text { 11. Blended learning is more effective } \\
\text { than traditional face- to- face } \\
\text { learning }\end{array}$ \\
\hline & $\begin{array}{l}\text { Public Transport versus Driving } \\
\text { in Singapore }\end{array}$ & $\begin{array}{l}\text { 12. Public means of transport will soon } \\
\text { replace private ones in big cities. }\end{array}$ \\
\hline & Book versus Movie Adaptations & $\begin{array}{l}\text { 13. Reading a novel is much more } \\
\text { enjoyable than watching a movie } \\
\text { based on it. }\end{array}$ \\
\hline & $\begin{array}{l}\text { Working Part-time } \\
\text { University- Advice }\end{array}$ & $\begin{array}{l}\text { 14. All university level students should } \\
\text { have part- time jobs. }\end{array}$ \\
\hline & $\begin{array}{l}\text { Technology is Replacing Jobs. } \\
\text { Are You Ready? }\end{array}$ & $\begin{array}{l}\text { 15. Modern technology and } \\
\text { automation are the main cause of } \\
\text { unemployment. }\end{array}$ \\
\hline \multirow[t]{5}{*}{ Ten } & $\begin{array}{l}\text { Should We Raise the Driving } \\
\text { Age? }\end{array}$ & $\begin{array}{l}\text { 16. 'Twenty One' should be the legal } \\
\text { driving age around the world. }\end{array}$ \\
\hline & $\begin{array}{l}\text { How Safe It Is to Fly in a Plane- } \\
\text { A Pilot's Perspective }\end{array}$ & $\begin{array}{l}\text { 17. Air travel is the safest form of } \\
\text { travelling. }\end{array}$ \\
\hline & $\begin{array}{l}\text { Home Schooling versus Public } \\
\text { Schooling- five differences } \\
\text { explained }\end{array}$ & $\begin{array}{l}\text { 18. Home schooling has more } \\
\text { advantages than disadvantages. }\end{array}$ \\
\hline & $\begin{array}{l}\text { What Does It Take to } \mathrm{Be} \text { a } \\
\text { Fashion Designer? }\end{array}$ & $\begin{array}{l}\text { 19. Fashion design has become more } \\
\text { of a profitable industry than an } \\
\text { exhibition of talent and genuine } \\
\text { art. }\end{array}$ \\
\hline & $\begin{array}{l}\text { Yaron Answers- What's Wrong } \\
\text { with Free Health Care? }\end{array}$ & $\begin{array}{l}\text { 20. Health care should be free for all } \\
\text { citizens. }\end{array}$ \\
\hline
\end{tabular}

As highlighted in table (6), the previously mentioned online videos watched prior to debating activated the students' prior knowledge of the debate topic and encouraged them to formulate their points of view with regards to the debated ideas. 
Ebtihal A. Helal, Ph.D.

\begin{tabular}{|c|c|c|}
\hline $\begin{array}{l}\text { Session } \\
\text { No. }\end{array}$ & Title of the Podcast & Source \\
\hline One & Internet- Good or Bad? & $\begin{array}{l}\text { BBC } 6 \text { Minute Learning } \\
\text { English }\end{array}$ \\
\hline Two & $\begin{array}{l}\text { English for Medicine- A } \\
\text { doctor's View }\end{array}$ & \multirow[t]{5}{*}{$\begin{array}{l}\text { The British Council } \\
\text { podcasts }\end{array}$} \\
\hline Three & Complaining & \\
\hline Four & $\begin{array}{l}\text { Biotechnology: Is Genetically } \\
\text { Modified Food Good or Bad? }\end{array}$ & \\
\hline Five & Going Global & \\
\hline Six & Emotional Intelligence & \\
\hline Seven & What's happiness? & $\begin{array}{l}\text { BBC } 6 \text { Minute Learning } \\
\text { English }\end{array}$ \\
\hline Eight & May Day & podcastinenglish.com \\
\hline Nine & Improving Your Memory & $\begin{array}{l}\text { BBC } 6 \text { Minute Learning } \\
\text { English }\end{array}$ \\
\hline Ten & Gadgets: Useful or Useless? & podcastinenglish.com \\
\hline
\end{tabular}

As shown in table (7), the podcasts analyzed in the post- task phase were closely related to the online collaborative tasks practised in each session to further stress their distinctive features and enhance the study group students' speaking performance in the subsequent sessions.

Table (8) Titles of the five online pronunciation videos watched for further pronunciation practice in the post- task phase

\begin{tabular}{|l|l|l|}
\hline Session No. & Title of the online video & Source \\
\hline Three & $\begin{array}{l}\text { Questions and Intonation: Up or } \\
\text { Down? }\end{array}$ & $\begin{array}{l}\text { Rachel's English.com } \\
\text { website }\end{array}$ \\
\hline Four & $\begin{array}{l}\text { Question vs. Statement } \\
\text { Intonation }\end{array}$ & \\
\hline Seven & $\begin{array}{l}\text { How to Say-ed Ending in } \\
\text { English }\end{array}$ & $\begin{array}{l}\text { To Learn English.com } \\
\text { website }\end{array}$ \\
\hline Ten & English Fluency Tips- Elision & YouTube \\
\cline { 2 - 3 } & $\begin{array}{l}\text { British Pronunciation Lesson- } \\
\text { Assimilation }\end{array}$ & \\
\hline
\end{tabular}


As illustrated in table (8), the online pronunciation videos watched in the post- speaking phase focused on English intonation patterns for both questions and statements as well as three different ways of pronouncing the -ed inflectional morpheme used in regular past and past participle forms. They, also, highlighted two main aspects of connected speech, i.e., elision and assimilation. These videos were carefully selected to enhance the study group students' accurate intelligible pronunciation while speaking.

\section{Speaking tasks \& activities}

Throughout the proposed program, the experimental group students were required to practise varied Internet- based collaborative speaking tasks and activities to develop their overall speaking performance as well as the specified speaking sub-skills. These tasks and activities were carried out in collaborative groups first and then shared with the whole class.

Thus, throughout the program, students practised three major types of Internet- based collaborative tasks. These were (1) watching online videos and then using online sources to have well-supported relevant debates based on these videos, (2) watching, retelling and commenting on online digital stories and (3) using online written, visual and video resources to give multi-media PowerPoint oral presentations discussing the causes, effects and previous solutions of current societal problems and suggesting new possible solutions. These tasks were alternatively practised throughout the program implementation where debating was practised in sessions one, four, seven and ten, and digital stories retelling and commentary were practised in sessions two, five and eight. As for multimedia PowerPoint group presentations, they were delivered in sessions three, six and nine.

In addition, a wide variety of online group activities were practised throughout the program implementation in the pre- task and post- task phases. The aim of these activities was to provide the experimental group students with varied opportunities to further practise and develop the specified speaking sub-skills, thus fostering their overall speaking proficiency.

\section{Duration of the treatment}

After designing the proposed program and its teaching strategy, it was presented to a panel of jury and modified according to their suggestions. Then, the researcher randomly selected twelve first year EFL intensive English course students and implemented three selected sessions with them with one session for each type of the collaborative 


\section{Ebtihal A. Helal, Ph.D.}

tasks. Based on this pilot study of the proposed program, it was indicated that the Internet- based collaborative speaking tasks were suitable for the students' age, background knowledge and linguistic proficiency levels.

The pilot study students maintained that they found these tasks quite motivating and engaging. They liked the debating session most as they maintained it helped them to examine ideas from different perspectives and evaluate evidence. They also stated that the digital storytelling session enabled them to see the role of technology in modernizing the traditional art of storytelling. Furthermore, they viewed the multi-media presentation task as a challenging one that helped them to become more responsible for their learning.

Through the pilot study, it was also evident that each session required 180 minutes (three hours) to enable the students to carry out the tasks, reflect upon them and do the post- task activities. In addition to the introductory session- where students were introduced to the program objectives and the three online collaborative tasks-, the implementation of the proposed program lasted for ten sessions over a period of two months and a half during the Spring Semester of the 2017- 2018 academic year. The experimentation started on Februray $18^{\text {th }}$. , 2018 and ended on May, $7^{\text {th }}, 2018$.

The proposed teaching strategy followed throughout the online collaborative tasks sessions

The researcher followed a proposed teaching strategy throughout the program implementation with the experimental group students. This strategy was based on the previously highlighted pedagogic framework of a task- based lesson designed by Willis (1996).

According to this teaching strategy, each speaking session was divided into three phases. These phases were as follows:

\section{Pre-task phase}

II. The task cycle

\section{Post- task phase}

These phases could be explained as follows:

\section{Pre-task phase:}

a. This phase aimed at preparing the students for the Internet- based collaborative speaking tasks. This was achieved through (1) randomly assigning the students into their collaborative groups, (2) introducing the students to the session focus and task and (3) raising their consciousness of the speaking tasks requirements and relevant linguistic features.

b. As the teacher introduced the session focus and task, students were 
randomly assigned by the teacher into their collaborative groups as follows:

- In the debating sessions, the thirty students were divided into five groups of six students each. Each group was offered the chance to choose the debate topic they were interested in from the list of twenty debate topics offered by the teacher. Once each group members decided upon the topic they wanted to have a debate on, these six students were randomly assigned by the teacher into two groups of three. Each three students belonged either to the affirmative (proposition) group or the negative (opposition) group.

- In the digital storytelling and multimedia PowerPoint oral presentation sessions, the thirty students were divided into six collaborative groups of five students each. Each group was offered the chance to choose the oral presentation topic or the digital story to be watched from a list of eighteen oral presentation topics and eighteen online digital stories offered by the teacher.

c. The teacher encouraged the students' selection of the debate and oral presentation topics as well as the digital story to be watched to maintain their interest, involvement and motivation throughout the task implementation. This was, also, done to foster their sense of ownership and responsibility while implementing the task.

d. After the students settled down in their groups- that constantly changed from one session to another to help them benefit from each other's strengths, go beyond their comfort zones and increase their interactional opportunities-, came the step of consciousnessraising. This was achieved as the students watched carefully selected (a) online BBC Learning English pronunciation short videos distinguishing confusing sounds, (b) online British Council grammar videos focusing on specific grammatical rules and patterns as well as (c) online videos of similar oral presentations and debates in addition to online digital stories to analyze them in class before doing the speaking task. It is important to note, here, that the problematic sounds and grammatical rules were identified 


\section{Ebtihal A. Helal, Ph.D.}

by the researcher/ teacher as a result of analyzing the experimental group students' performance on the speaking pre-test.

e. As the students watched the online pronunciation short videos, they were required to listen attentively to and repeat the examples highlighted in the videos of these confusing sounds. They were, also, required to come up with more examples of these sounds in their groups first and share them with the rest of the class to check that they have acquired the correct pronunciation of these sounds.

f. As the students watched the online British Council Learn English Teen grammar videos, they were asked to identify examples of the rules or grammatical patterns highlighted in the videos. To facilitate the students' task, the teacher handed in the transcripts of the grammar videos to assist the learners and raise their consciousness of these grammatical rules. The researcher/ teacher purposefully selected these grammar videos because they highlighted the grammatical forms or patterns in the context of a real life story, situation or conversation. Thus, while they aimed at promoting EFL learners' grammatical accuracy, meaning and communication of ideas were also stressed. In addition, these animated videos were quite appealing and motivating for the learners, and they were followed by useful relevant practice exercises that were used in the post- task phase.

g. After raising students' consciousness of necessary pronunciation and grammar aspects, students in their collaborative groups were required to analyze similar speaking tasks of debating and oral presentations to identify the linguistic features and the structure of each task, thus breaking down each task into more manageable components to facilitate subsequent task implementation. As for the digital story retelling and commentary task, students watched sample digital stories and analyzed them in their groups first and then with the whole class to prepare them for the following similar task in their respective groups.

h. After the students watched the sample online debates, oral presentations or digital stories, they were required in their collaborative groups to:

- identify more examples of the grammatical rules and sounds 
highlighted earlier in the previously watched videos;

- analyze them using their transcripts to identify the fillers and fixed expressions used by the speaker(s) to maintain fluency.

- note the rhythm of the speech and the communication strategies adopted to fluently get the message across;

- identify the pragmatic functions of specific expressions and speech acts that were earlier highlighted by the teacher in the sample speeches transcripts;

- evaluate the sample speeches in terms of their coherence, cohesion, comprehensibility and ideas development with the help of guiding questions offered by the teacher; and

- underline examples of useful debating, presentation and storytelling vocabulary and expressions in the videos transcripts and then share them with the whole class.

\section{The task cycle:}

a. Throughout the task cycle, students planned for their Internet- based collaborative tasks; they drafted, rehearsed, did the task with the teacher's guidance and reported it through their classroom public performance.

b. Thus, students- in their collaborative groups- started preparing themselves for the speaking task and rehearsed it before actually doing it in front of the class. This step went as follows:

In the debating sessions, members of the affirmative and negative teams had to collaboratively search for and use at least two reliable Internet sources to support their stance and refute the other team's counter arguments.

In the multimedia oral presentation sessions, students had to use at least two online recent written sources to discuss the causes, effects and solutions of the problems investigated. They were also required to log onto the Internet and download varied expressive images and a carefully selected video to accompany 


\section{Ebtihal A. Helal, Ph.D.}

and enhance the quality of their oral multimedia PowerPoint presentations.

In the online digital story retelling and commentary session, they had to discuss each digital story, its theme, main characters, events and moral lesson; they had, also, to comment on each story they watched considering giving it a new beginning, climax and/ or a new ending.

c. Whenever some students felt confused as they read the online sources for the debates and oral presentations or as they were preparing themselves for the debate or the public speech, they were encouraged to help each other in their collaborative groups so that the more knowledgeable learner helped the less knowledgeable. In case students were unable to guess the meanings of new words in their online sources or were confused as to the precise expressions to use in their collaborative talk, they were encouraged to use online dictionaries to help them in that respect. These dictionaries included Macmillan dictionary: Free English Dictionary and Thesaurus Online ( available at https://www.macmillandictionary.com/) , Cambridge Dictionary: English dictionary Translations \&Thesaurus' ( available at https://dictionary.cambridge.org/) , Oxford Dictionaries ( available at https://en.oxforddictionaries.com/) and Collins Free Online Dictionary (available at https://www.collinsdictionary.com/)

d. As the students used these dictionaries, they were able to find more relevant information regarding word definitions, synonyms, pronunciation and sometimes collocations as well as example sentences.

e. Then, each group members had to discuss among themselves the language forms, vocabulary and expressions needed to carry out the speaking task. In case, they needed more vocabulary help, they were allowed to access the previously highlighted online dictionaries.

f. Students were, also, encouraged to access grammar online 
sources like English Grammar Online (available at https://www.ego4u.com/en/cram-up/grammar),

Grammar.com (available at https://www.grammar.com/) and English Grammar Guide (available at https://www.ef.com/wwen/english-resources/englishgrammar/) to check the accuracy of their speech.

g. Students were advised to equally divide the task among themselves so that every group member will have his/ her fair share to participate in the task and express himself/ herself.

h. As the students rehearsed their collaborative speech, they were guided with the help of a self- assessment checklist to make sure that their oral presentation should:

* reflect thorough knowledge of the problem under investigation;

illustrate strong levels of co-ordination among the team members who should share the responsibility of the overall quality of the group speech;

* display effective presentation skills including varying the voice tone, projecting self-confidence, using expressive facial expressions and gestures as well as adhering to the presentation time limit;

* provide evidence that the team members were able to both design and deliver an engaging concise and precise multimedia PowerPoint presentation and adequately address the audience's comments and questions after giving the presentation;

acknowledge the online sources from which the students got the facts and details about the problems causes, effects and previous solutions; and

be quite thought-provoking by introducing two new proposed solutions to each problem and involving the audience in evaluating the expected effectiveness of such solutions. 


\section{Ebtihal A. Helal, Ph.D.}

i. As the students rehearsed for the debates, they were offered a self- assessment checklist to make sure that they:

clarified their stance from the very beginning;

provided enough documented evidence and facts to support their viewpoints;

* refuted the other team's counter arguments using convincing facts, examples and relevant evidence;

logically attacked the ideas, not attacked the persons who presented the ideas;

* kept their debate to the point and did not divert to unimportant side issues;

showed respect to each other's viewpoint while keeping their right to think differently about the same issue;

* equally distributed the debating task so that every member whether in the affirmative or negative team had his/ her fair share to express himself/ herself, thus adding to the overall strength of the team's position; and

ended the debate in a friendly civilized manner.

j. As the students rehearsed retelling and commenting on the watched online digital stories, members of each collaborative group used a self- assessment checklist provided by their teacher to ensure that their talk:

- introduced the listeners to the type of the online digital story they watched (i.e., whether it was a personal narrative, a historical documentary or an informative story that was mainly told to instruct the audience about something);

- set the scene for the story by highlighting its time, place, main characters and theme;

- critically commented on the story incidents and information, stating the reason why they liked or disliked it;

- highlighted whether they would recommend that other students should or should not watch it and the reason for that; 
- creatively discussed a new beginning, climax or ending that would make the story more appealing and engaging to its viewers; and

- welcomed the listeners' clarifying questions, comments and opinions with regards to the story they heard and discussed.

k. While rehearsing and planning for the task, the teacher rotated among the groups, offering help and advice only when needed to foster the learners' independence and sense of responsibility for their own learning.

1. After that, collaborative groups started one after the other reporting the tasks at hand through giving their public speeches. They followed the previously highlighted guidelines and coordinated their work as one team while the rest of the class and the teacher were attentively listening to each group to judge the speech overall quality and give their own comments.

m. Each group was allowed a time limit of fifteen minutes to have a debate, give their oral presentation or retell and comment on the watched online digital story. After each public performance, the audience was given five minutes to further inquire, comment or ask questions, thus fostering the students' authentic speaking chances.

n. As each collaborative group gave its speech, they tried hard to make sure that they maintained their fluency using fillers, fixed expressions, adequate rhythm and communication strategies. They, also, tried to use clear intelligible pronunciation, accurate vocabulary and correct grammatical forms. In addition, they used coherence markers and cohesive devices to make their speech as coherent, cohesive and comprehensible as possible. Following their teacher's guidance, they did their best to check that their speech offered enough details and support to the ideas presented and performed the functions it was intended to perform. 
o. The teacher encouraged the students to speak confidently and did not interrupt the group members when they made occasional local errors. However, when some group members made global errors that hindered the comprehensibility of their talk, the teacher interrupted nicely asking them to clarify their speech by rephrasing it or giving examples.

p. As each student talked in his/ her group, the teacher listened attentively and used separate copies of the analytic speaking rubric to offer each student informative feedback on the speaking strengths, weaknesses and areas of further development. Students were given their rubric copies at the end of each session and were allowed to discuss this feedback in detail, if they wanted to, in the one-to- one conferences that took place after each session. In addition, students received informative feedback on group dynamics that were assessed on a scale from four to one as follows:

\begin{tabular}{|c|c|c|c|c|}
\hline \multirow{2}{*}{$\begin{array}{l}\text { Group } \\
\text { dynamics }\end{array}$} & Very Good (4) & Good (3) & Fair (2) & Poor (1) \\
\hline & $\begin{array}{l}\text { Consistently } \\
\text { adequate co- } \\
\text { ordination } \\
\text { among the team } \\
\text { members } \\
\text { throughout the } \\
\text { speech where } \\
\text { every team } \\
\text { member is given } \\
\text { a fair chance to } \\
\text { share his/ her } \\
\text { viewpoints. }\end{array}$ & $\begin{array}{l}\text { Mostly } \\
\text { adequate co- } \\
\text { ordination } \\
\text { among the } \\
\text { team } \\
\text { members } \\
\text { although one } \\
\text { of the team } \\
\text { members } \\
\text { seems to } \\
\text { slightly } \\
\text { dominate the } \\
\text { talk and hold } \\
\text { the floor }\end{array}$ & $\begin{array}{l}\text { Some co- } \\
\text { ordination } \\
\text { among the } \\
\text { team } \\
\text { members } \\
\text { although } \\
\text { one or two } \\
\text { speakers } \\
\text { obviously } \\
\text { dominate } \\
\text { the talk, } \\
\text { making the } \\
\text { role of the } \\
\text { rest of the } \\
\text { team } \\
\text { members } \\
\text { more } \\
\text { marginal } \\
\text { and less } \\
\text { influential }\end{array}$ & $\begin{array}{l}\text { Little or no } \\
\text { co-ordination } \\
\text { among the } \\
\text { team } \\
\text { members. } \\
\text { Speakers } \\
\text { introduce } \\
\text { themselves } \\
\text { and one } \\
\text { speaker is } \\
\text { obviously } \\
\text { holding the } \\
\text { floor making } \\
\text { the speech } \\
\text { look more of } \\
\text { an individual } \\
\text { work than a } \\
\text { collaborative } \\
\text { one }\end{array}$ \\
\hline
\end{tabular}


The Effectiveness of a Proposed Internet- Based Collaborative Tasks Program in Developing EFL Speaking Skills among Egyptian University Level Students

\section{Post- task phase:}

a. This stage offered the students more opportunities to (a) reflect upon and self- assess their oral performance, (b) do further spoken discourse analysis and (c) practise more the specified speaking subskills.

b. After all the class groups finished their public oral performance, members of each group were offered the chance to self- assess their speech within their group at first and then share this selfassessment with the whole class and the teacher. In order to make this reflection stage more systematic and informative, students used self-assessment criteria provided by the teacher and based on the speaking analytic rubric.

c. Sharing the group self- assessment with their teacher and the whole class was carried out through a group representative- that was changed for each task to ensure that all the students had a fair chance to share their viewpoints and ideas, thus shouldering the responsibility for their learning.

d. After reflecting upon and self- assessing their oral performance, students listened attentively to carefully selected online podcasts. In each session, they were asked to analyze a relevant podcast with the help of its transcripts in their collaborative groups to see how far the speaker(s) (a) pronounced words clearly and accurately, (b) maintained their fluency, grammatical accuracy and comprehensibility, (c) developed their ideas, (d) performed varied functions with their speech and (e) used precise accurate vocabulary. This collaborative group analysis was later on shared with the rest of the class and the teacher, who encouraged more students' interactions and contributions.

e. This was followed by the students' further practice of the specified speaking sub-skills as the students did more online practice exercises in their collaborative groups first and then discussed their answers with the rest of the class. These exercises were selected by the teacher from varied websites or uploaded by the teacher on the university e-learning website. Thus, this further practice step went as follows for each skill: 


\section{Pronunciation}

Each session, students were allowed the chance to further practise one of the relevant pronunciation features of word and sentence stress, statements and questions intonation patterns, weak and strong forms, consonant clusters, elision and assimilation on different carefully selected websites such as Word Stress Rules: A guide to Word and Sentence Stress Rules for English Language Teachers and Learners website (available at https://www.wordstress.info/word-stress-exercises/wordstress-exercise/), Question Tag Intonation Website ( available at https://thesoundofenglish.org/question-tag-intonation/) and Teaching English: Consonant Cluster website (available at https://www.teachingenglish.org.uk/article/consonant-cluster). In addition, students were asked to do more pronunciation practice exercises uploaded by the teacher on the university e- learning website.

\section{Pragmatic competence}

For each session, students read a group of given situations written and uploaded by the teacher on the university e-learning website. Students were required to read and discuss in their collaborative groups the expressions they could use to perform the functions highlighted in the prompts. Then, they shared their answers with the whole class. These situations were related to the session focus. Thus, for the debate session, they were asked to agree or disagree to a certain statement, providing reasons for their opinion; they were, also, asked to refute someone's counterarguments. In the oral presentation session, they were asked to discuss the causes, effects and previous solutions of given problems or suggest new possible solutions. In the digital storytelling session, they were required to use adequate expressions to retell or comment on varied famous stories/ movies.

\section{* Vocabulary}

In each session, the teacher helped the students expand their vocabulary by providing them with varied exercises from different websites on a specific vocabulary aspect like suffixes, prefixes, idioms, phrasal verbs, collocations, synonyms, antonyms and word groups. Examples of these websites included Really Learn English website (available at https://www.really-learn-english.com/prefixes-and-suffixesworksheets.html), Jimmy ESL: Free ESL idioms Worksheet website (available at https://jimmyesl.com/esl-resources/free-english-idiomsworksheets/ ) and English Maven- Helping Students Improve their English-

One

Step at 
http://www.englishmaven.org/HP6/Intermediate\%20Antonyms\%20Exerc ise\%2014.htm).

\section{Fluency and Ideas development \& comprehensibility}

Students were offered the chance to further practise these skills when each group was given the chance to speak non-stop for two minutes on one of the areas highlighted on the e-learning website. These speaking areas included family relations, sports, shopping, vacations, travel, future careers, friends, technology, customs, traditions, the weather, clothing, food, media, cinema, university life, festivals and celebrations. Students in each group were asked to prepare for this speech in three to five minutes before they spoke non-stop in front of the class trying to make their speech as coherent, cohesive, well-developed and comprehensible as possible while maintaining its fluency.

\section{Grammar}

Students answered varied selected online exercises on the British Council Learn English Teens Website. These exercises were based upon to the grammatical patterns and rules highlighted earlier in the pre- task phase. These exercises covered the areas of tenses, comparative and superlatives, conjunctions, active and passive voice, countable and uncountable nouns as well as modal verbs indicating advice, necessity and prohibition.

f. According to the proposed teaching strategy, students were active participants in the pre-, during and post- task phases. They shouldered the responsibility for their speaking development in their collaborative groups. Furthermore, they supported each other, monitored their group and individual speaking performance and asked for teacher's guidance only when necessary. The teacher was a guide, a scaffolder and a facilitator who encouraged the students' use of varied online sources and websites to further develop their overall speaking performance as well as their speaking sub-skills.

\section{Instructional aids and equipment}

The following aids were used during the implementation of the current proposed program:

1. The three online YouTube videos watched in the introductory 


\section{Ebtihal A. Helal, Ph.D.}

session to introduce the students to the program collaborative speaking tasks

2. The online videos watched in the pre-debating stage to introduce the debating topics to the students

3. The online grammar and pronunciation videos watched in the pre-task phase to focus on the students' problematic grammatical and pronunciation aspects

4. The sample online debates, oral presentations and digital stories analyzed in the pre- task phase

5. The online dictionaries and grammar references used by learners to prepare for their speaking tasks

6. The varied websites visited by the students to collect enough reliable sources and information for the debates and multimedia oral presentations

7. The online digital stories watched by the students for the purpose of retelling and commenting on them

8. The YouTube online videos and Google images used by the students in their multimedia PowerPoint presentations

9. The varied online exercises focusing on the specified speaking sub-skills answered in the post- task phase

10.The online podcasts analyzed in the post- task phase

11.The collaborative group self-assessment form used each session to help learners identify their speaking strengths and weaknesses and monitor their progress

\section{Evaluation}

Formative evaluation took place throughout the proposed program implementation as the teacher used separate copies of the speaking analytic rubric to assess each student's overall speaking performance and speaking sub-skills in the online collaborative tasks. Students were encouraged to see and discuss their teacher's formative assessment on their analytic rubrics. Furthermore, whenever the students needed further feedback on their oral performance, they were allowed to individually discuss its strengths, weaknesses and future areas for further improvement as they had one-to-one conferences with the teacher at the end of each session.

At the end of the treatment, summative evaluation took place when the experimental group students took the speaking post-test. The aim of 
this summative evaluation was to measure the effectiveness of the proposed program in developing the experimental group students' overall speaking performance and the specified speaking sub-skills as compared to their pre-test performance.

\section{Statistical analysis of test results}

After the pre-/ post- administration of the speaking test on the experimental group, the researcher used Paired- Samples t tests in order to examine the validity of the study two hypotheses. Moreover, in order to make sure that the results obtained from the t- tests were reliable and to measure the effectiveness of the proposed program in developing the experimental group students' speaking sub-skills, its effect size was calculated according to Dunlap's (1994) formula.

\section{Results:}

\section{Results related to the study hypotheses were as follows:}

Hypothesis One: There is a statistically significant difference between the mean scores of the experimental group on the pre-test and the posttest in overall speaking in favour of the post- test.

To determine the relative extent of change fostered by the implementation of the proposed program from the pre-test to the post-test for the experimental group, a paired samples t-test was used. See table (9).

Table (9)

T- test results comparing the pre- test vs. post- test means for the experimental group in overall speaking

\begin{tabular}{|c|c|c|c|c|c|c|c|}
\hline Test & $\mathbf{N}$ & $\mathbf{M}$ & S.D. & D.F. & $\begin{array}{l}\text { t } \\
\text { value }\end{array}$ & $\begin{array}{l}\text { Significance } \\
\text { Level }\end{array}$ & \begin{tabular}{|l|} 
Effect \\
Size \\
\end{tabular} \\
\hline $\begin{array}{l}\text { Pre- } \\
\text { test }\end{array}$ & \multirow[t]{2}{*}{30} & 11.50 & 2.40 & \multirow[t]{2}{*}{29} & \multirow[t]{2}{*}{22.36} & \multirow{2}{*}{\begin{tabular}{ll}
\multicolumn{2}{l}{ Significant } \\
at & 0.01 \\
Level &
\end{tabular}} & 8.30 \\
\hline $\begin{array}{l}\text { Post- } \\
\text { test }\end{array}$ & & 18.77 & 1.22 & & & & Large \\
\hline
\end{tabular}

Table (9) indicates that there was a statistically significant difference at 0.01 level in overall speaking between the mean scores of the experimental group on the pre-test and the post-test in favor of the post-test since the estimated t- value was (22.36). Thus, it can be safely said that the t-test result proved to be statistically consistent with the hypothesis. Therefore, the first hypothesis was confirmed. In addition, the estimated effect size value (8.30) indicated that the program had a large 
effect on the experimental group students' overall speaking on the posttest as compared to their overall speaking on the pre- test.

The following figure illustrates the experimental group students' significant growth in overall speaking after the proposed program application as compared to their overall speaking performance on the pretest:

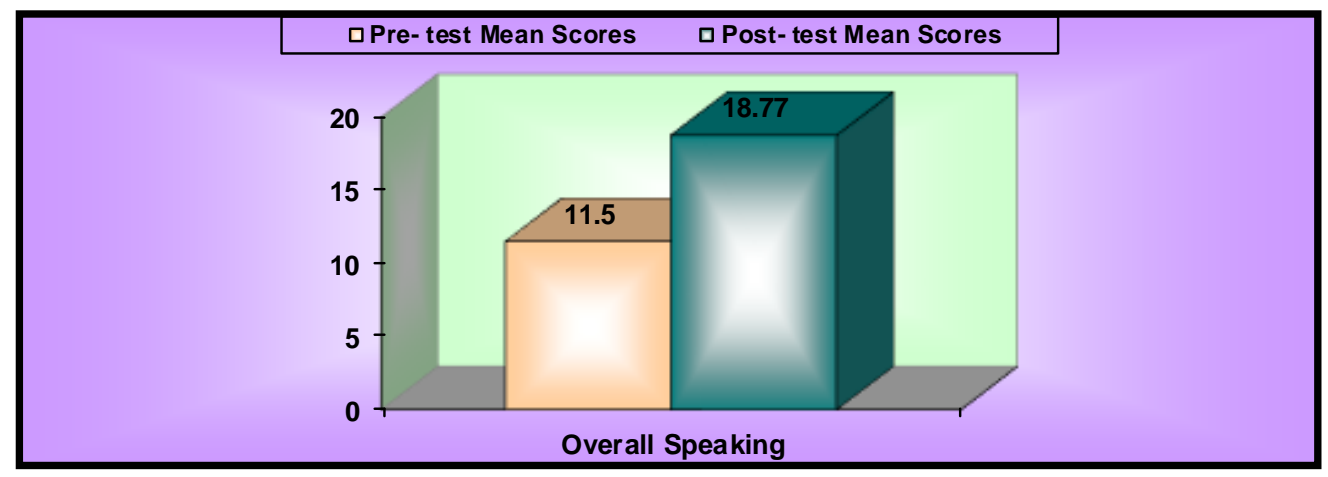

Figure (1)

\section{Comparison of the pre- test vs. post- test means for the experimental group in overall speaking}

Hypothesis Two: There are statistically significant differences between the mean scores of the experimental group on the pre-test and the post- test in each speaking sub-skill in favour of the post- test.

In order to verify the validity of the second hypothesis, paired samples $\mathrm{t}$ - tests were used. The $\mathrm{t}$ - test results proved that there were statistically significant differences between the mean scores of the experimental group on the pre-test and the post-test in pronunciation, fluency, grammar, vocabulary, ideas development \& comprehensibility as well as in pragmatic competence in favour of the post- test. In other words, results of the t- tests proved to be statistically consistent with the above stated hypothesis. Therefore, the second hypothesis was accepted.

The following table shows this statistical significance at 0.01 level. In addition, the calculated effect size values proved that the proposed program had a large effect on the experimental group students' performance in the specified speaking sub- skills. It should be also noted that the proposed program had the largest calculated effect size (6.66) on the experimental group students' performance on the post -test with regard to ideas development and comprehensibility. This, in turn, proves that Internet- based collaborative tasks can significantly foster EFL university level learners' ability to create cohesive, coherent and 
The Effectiveness of a Proposed Internet- Based Collaborative Tasks Program in Developing EFL Speaking Skills among Egyptian University Level Students

comprehensible spoken discourses with enough supporting details and examples.

Table (10)

T- Test results comparing the pre- test vs. post- test means for the experimental group in speaking sub-skills

\begin{tabular}{|c|c|c|c|c|c|c|c|c|}
\hline Speaking Sub- skill & Test & $\mathbf{N}$ & $\mathbf{M}$ & S.D. & D.F. & $\begin{array}{l}\text { t } \\
\text { value }\end{array}$ & $\begin{array}{l}\text { Significance } \\
\text { Level }\end{array}$ & $\begin{array}{l}\text { Effect } \\
\text { Size }\end{array}$ \\
\hline \multirow[t]{2}{*}{ Pronunciation } & $\begin{array}{l}\text { Pre- } \\
\text { test }\end{array}$ & \multirow[t]{2}{*}{30} & 1.97 & 0.72 & \multirow[t]{2}{*}{29} & \multirow[t]{2}{*}{11.93} & \multirow[t]{2}{*}{$\begin{array}{l}\text { Significant at } \\
0.01 \text { Level }\end{array}$} & 4.43 \\
\hline & $\begin{array}{l}\text { Post- } \\
\text { test }\end{array}$ & & 3.17 & 0.38 & & & & Large \\
\hline \multirow[t]{2}{*}{ Fluency } & $\begin{array}{l}\text { Pre- } \\
\text { test }\end{array}$ & \multirow[t]{2}{*}{30} & 1.77 & 0.57 & \multirow[t]{2}{*}{29} & \multirow[t]{2}{*}{15.70} & \multirow[t]{2}{*}{$\begin{array}{l}\text { Significant at } \\
0.01 \text { Level }\end{array}$} & 5.83 \\
\hline & $\begin{array}{l}\text { Post- } \\
\text { test }\end{array}$ & & 3.00 & 0.37 & & & & Large \\
\hline \multirow[t]{2}{*}{ Grammar } & $\begin{array}{l}\text { Pre- } \\
\text { test }\end{array}$ & \multirow[t]{2}{*}{30} & 1.80 & 0.41 & \multirow[t]{2}{*}{29} & \multirow[t]{2}{*}{13.57} & \multirow[t]{2}{*}{$\begin{array}{l}\text { Significant at } \\
0.01 \text { Level }\end{array}$} & 5.04 \\
\hline & $\begin{array}{l}\text { Post- } \\
\text { test }\end{array}$ & & 3.00 & 0.37 & & & & Large \\
\hline \multirow[t]{2}{*}{ Vocabulary } & $\begin{array}{l}\text { Pre- } \\
\text { test }\end{array}$ & \multirow[t]{2}{*}{30} & 1.83 & 0.38 & \multirow[t]{2}{*}{29} & \multirow[t]{2}{*}{16.16} & \multirow[t]{2}{*}{$\begin{array}{l}\text { Significant at } \\
0.01 \text { Level }\end{array}$} & 6 \\
\hline & $\begin{array}{l}\text { Post- } \\
\text { test }\end{array}$ & & 3.03 & 0.18 & & & & Large \\
\hline \multirow{2}{*}{$\begin{array}{l}\text { Ideas Development } \\
\text { \& } \\
\text { Comprehensibility }\end{array}$} & $\begin{array}{l}\text { Pre- } \\
\text { test }\end{array}$ & \multirow[t]{2}{*}{30} & 2.13 & 0.57 & \multirow[t]{2}{*}{29} & \multirow[t]{2}{*}{17.95} & \multirow[t]{2}{*}{$\begin{array}{l}\text { Significant at } \\
0.01 \text { Level }\end{array}$} & 6.66 \\
\hline & $\begin{array}{l}\text { Post- } \\
\text { test }\end{array}$ & & 3.27 & 0.52 & & & & Large \\
\hline \multirow[t]{2}{*}{$\begin{array}{l}\text { Pragmatic } \\
\text { Competence }\end{array}$} & $\begin{array}{l}\text { Pre- } \\
\text { test }\end{array}$ & \multirow[t]{2}{*}{30} & 2.00 & 0.46 & \multirow[t]{2}{*}{29} & \multirow[t]{2}{*}{15.28} & \multirow[t]{2}{*}{$\begin{array}{l}\text { Significant at } \\
0.01 \text { Level }\end{array}$} & 5.67 \\
\hline & $\begin{array}{l}\text { Post- } \\
\text { test }\end{array}$ & & 3.30 & 0.47 & & & & Large \\
\hline
\end{tabular}

The following two figures illustrate the experimental group students' significant growth in each speaking sub-skill after the proposed program application as compared to their performance on the pre- test: 


\section{Ebtihal A. Helal, Ph.D.}

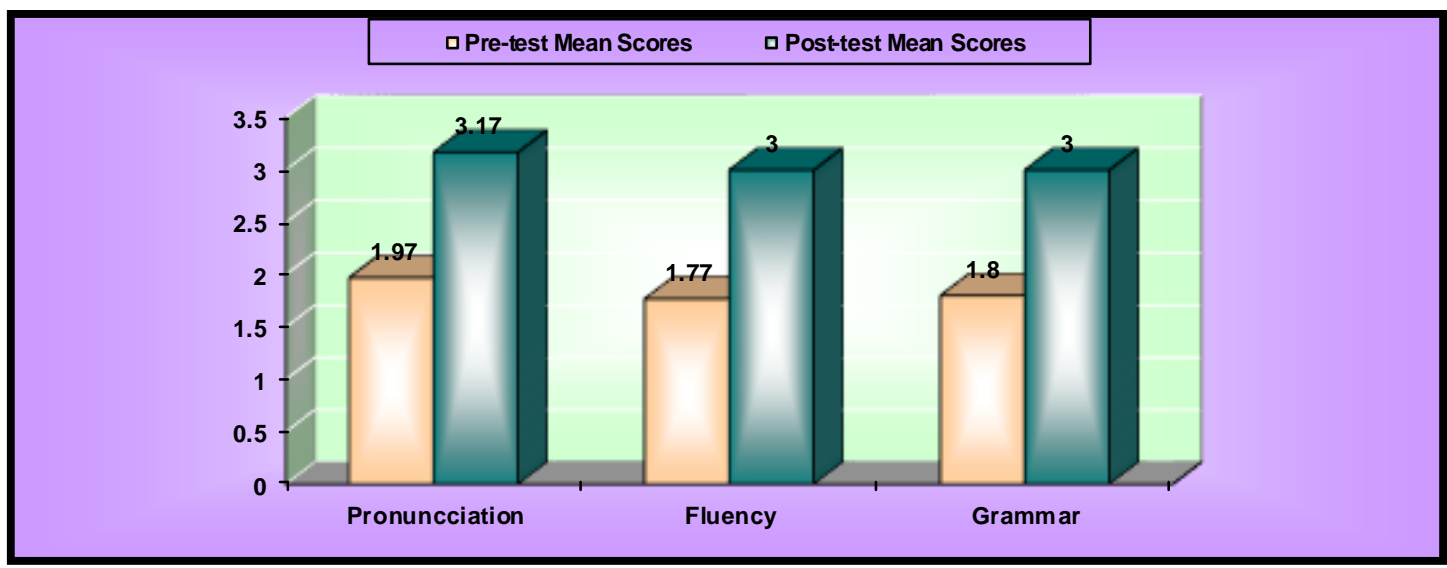

\section{Comparison of the pre- test vs. post- test means for the experimental group in pronunciation, fluency and grammar}

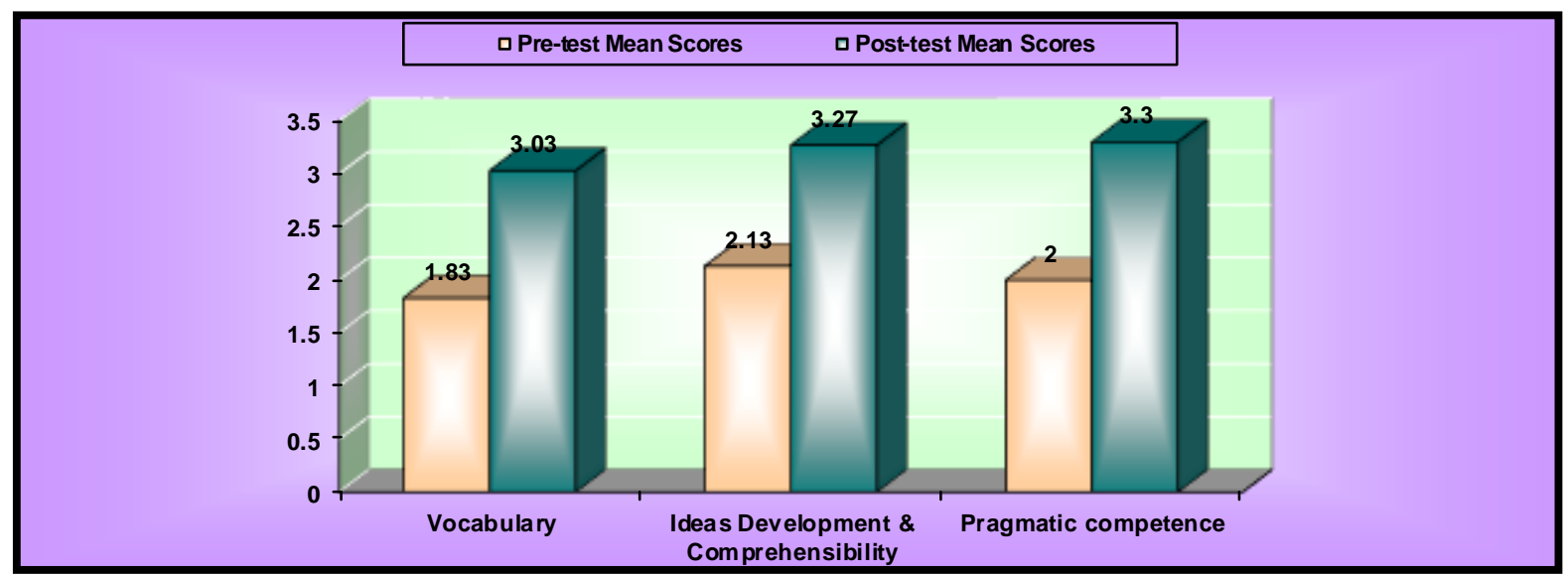

To sum up, support was gained for both of the study hypotheses. The experimental group students achieved tangible progress in their speaking sub-skills after the implementation of the proposed program as compared to their speaking performance before the program application.

\section{Discussion}

The post- test results revealed that the implemented Internet- based collaborative tasks program was effective in developing the experimental group students' overall speaking and speaking sub-skills. There was tangible evidence that these Internet- based collaborative tasks helped the students plan for their speaking, use varied online sources to carry out the speaking tasks, collaborate to achieve a real- life outcome and self- assess their speaking performance. Such results provide further emphasis to the idea that Internet- based collaborative learning can foster EFL learners' language skills as highlighted by Warschauer, Shetzer \& Meloni (2000) and Brown (2007a). In addition, the current study findings are consistent 
with the findings of the previous studies of Pattenpitchet (2011) and Gamba (2013) which indicated that collaborative tasks foster EFL speaking skills among university level learners.

The study findings are also consistent with the findings of the studies conducted by Kirkgöz (2011), Ismaili (2013), Ho and Long (2014), Ji (2014), Mohammadipour \& Rashid (2015), Hamouda (2016), Sariçoban \& Karakurt (2016), Córdoba Zúñiga (2016) and Yousif (2017) indicating that Task- Based Instruction enhances EFL speaking proficiency among university level learners. Moreover, the present study findings is a contribution to the field of Internet- based collaborative tasks as no previous study, to the researcher's best knowledge, has investigated the impact of such tasks on developing EFL speaking skills among university level learners despite the fact that the two previous studies of Cizinauskiene, Daubariene and Marcinkoniene (2002) and Choi (2008) indicated the effectiveness of such tasks in developing EFL writing skills whereas the study of Al-Rawahi and Al- Makhlafi (2015) stressed their positive impact on developing Omani EFL university level learners' reading, writing and attitude.

The current study results are consistent with the previous studies findings of Baghdasaryan (2012), Somdee (2012), Dekdouk (2013), Ben Alahem (2013), Kim (2014), Rokni \& Qarajeh (2014), Pardo (2014), Sabbah (2015), Fauzan (2016), Fauzi (2016) and Abdelmageed \& ElNaggar (2018) highlighting the positive impact of debates, oral presentations and digital storytelling on promoting EFL speaking skills among university level learners.

Throughout the program implementation, the experimental group students practised using varied online audio-, audio- visual, written and visual sources to carry out their collaborative speaking tasks. Such sources were carefully interwoven into the program sessions to enrich the students' speaking practice, open new windows of insight for the learners and foster their motivation as well as their task engagement through the sense of discovery accompanying the Internet surfing process. The purposeful meaningful nature of the program tasks with their real- life outcomes fostered the learners' self-confidence, autonomy and interdependence. In addition, these tasks of debating, giving multimedia oral presentations as well as online digital stories retelling and commentary were suitable for university level learners' cognitive maturation and their growing tendency to analyze ideas and concepts as indicated by Brown (2007b). 
Encouraging learners to collaborate in their groups to carry out their speaking tasks gave each student an equal share of the task and allowed the less knowledgeable students to receive help from the more knowledgeable ones in a relaxing classroom atmosphere. Such an atmosphere lowered the shy less motivated students' affective filter and allowed them to benefit from the teacher's guidance and support only when necessary, thus relying more on themselves. In addition to the collaboration among group members, there was a sense of competition between groups as each group tried hard to give their best public oral performance, thus outperforming other groups. This sense of competition led learners to exert more efforts to perfect their public speaking and receive the teacher's and other students' recognition.

A crucial factor that led to the students' tangible speaking progress was the wide variety of the debating and oral presentation topics as well as the digital online stories watched by the students. Such a variety made the speaking tasks quite engaging, enriching, interesting and relevant to the students' everyday lives, and this, consequently, had a positive impact on their speaking ability. In addition, the specified speaking sub-skills were stressed through varied consciousness- raising activities in the pretask phase, purposefully developed in the context of the during- task phase and further emphasized in the reflection, analysis and further practice activities of the post- task phase.

The fact that the student had ample time to prepare for and rehearse their speaking tasks before doing the tasks in front of the classroom minimized their stage fright and made them more fluent confident speakers. In addition, the similar debating, oral presentation and digital story samples analyzed in the pre-task stage facilitated the students' speaking tasks as these samples provided the students with useful guidelines of what was expected from them when they did such speaking tasks in public.

The public performance of the speaking tasks emphasized their authenticity and encouraged the students to exert more efforts to make their speech as eloquent, fluent and comprehensible as possible. Thus, while one collaborative group was doing the task in public, the other groups were listening attentively to judge the speech overall quality, comment on it and ask questions. Furthermore, the self- assessment checklists used by the learners throughout the program implementation and the post- task reflections helped the students gradually enhance their speaking performance, identify their strengths and work hard on overcoming their speaking weaknesses.

The analysis of the online podcasts in the post- task phase gave the students more chances to see how competent speakers give effective 
successful speeches that illustrate their mastery of the different speaking sub-skills. Thus, these online podcasts provided students with tangible examples to follow to improve their speaking proficiency. Furthermore, the post- speaking online exercise where students were allowed to speak non- stop in their groups for two minutes made them more self- confident and more proficient speakers who tried as much as they could to strike the necessary balance between accuracy and fluency.

The formative assessment conducted by the teacher- with the help of the speaking analytic rubric at the end of each session- made learners more conscious of their strengths and the speaking sub-skills they needed more practice on. Moreover, the one-to-one conferences held at the end of each session with the students who needed more feedback on their speaking performance offered struggling speakers with practical tips to handle their speaking difficulties and become more fluent speakers.

As far as grammar is concerned, the experimental group students achieved noticeable progress in this skill as they identified- in their collaborative groups- examples of the grammatical rules or patterns highlighted in the British Council online grammar videos watched as part of the consciousness- raising activities. In addition, they were required to identify examples of these grammatical rules and patterns in the sample online debates, oral presentations and digital watched before doing the speaking tasks. During the speaking tasks, students tried hard to follow the grammatical rules to produce accurate meaningful utterances. In the post- speaking phase, students were required to further practice these grammatical rules and patterns as they did a number of online collaborative activities on the same website. These activities included (a) MCQs, (b) filling in gaps in given sentences, (c) matching two halves of sentences, (d) correcting grammatical errors in given sentences, (e) rearranging words to form correct sentences and (f) matching pictures with the correct countable or uncountable nouns.

The experimental group students' ability to use clear accurate intelligible pronunciation substantially developed as they watched, listened to and repeated the selected problematic sounds highlighted in the BBC Learning English online videos for consciousness- raising purposes. Then, they were asked to come up with more examples of their own exemplifying the correct pronunciation of these sounds. They were, also, asked to find further examples of these sounds in the sample debates, oral presentations or digital stories watched in the pre- task phase. 
During the speaking tasks, students tried as much as they could to use intelligible clear pronunciation. Furthermore, in the post-task phase, students were allowed the chance to further practise the skill of pronunciation as they did the collaborative online activities of (a) identifying the stressed syllables in words, (b) identifying the most stressed content word in given sentences, (c) reading aloud yes/no, whand tag questions as well as statements and then identifying their intonation patterns, (d) reading aloud and underlining the stressed syllables in word-class pairs according to their categories, (e) selecting the correct -ed ending pronunciation in given regular past form verbs, (f) listening to and repeating words that contain consonant clusters, then highlighting the consonant clusters in these words, (g) identifying and repeating the weak forms heard in given sentences and (h) providing more elision and assimilation examples. These pronunciation activities were accessed by the students on the intensive English course e-learning website as well as on thesoundofenglish.org and tolearnenglish.com websites.

The experimental group students' speaking sub- skill of vocabulary was noticeably developed through consciousness-raising activities that directed the students to log onto varied websites to examine and repeat the expressions used to argue for or against a stance, refute counter arguments, introduce, give and conclude an oral presentations, highlight the causes, effects and solutions of a problem and retell as well as comment on digital stories. Furthermore, as students watched the sample online debates, presentations and digital stories, they were required to locate examples of these expressions in the sample speeches. During speaking, students tried to use these expressions to make their speeches more expressive and comprehensible. In the post- task phase, students practised the online collaborative vocabulary activities of (a) completing sentences using suitable words, (b) completing words using correct suffixes, (c) choosing the correct verbs that collocate with the given expressions in sentences, (d) underlining the odd words in given sets of words, (e) matching English idioms with their meanings and (f) choosing the best synonyms or antonyms for given words.

. When it comes for the speaking sub-skill of fluency, as the students watched the sample online debates, oral presentations and digital stories in the pre- task phase, they were asked to identify examples of fillers and fixed expressions used by speakers to maintain fluency; they were also asked to note the rhythm of the speech and the compensatory communication strategies adopted by the speaker(s) in these samples to keep the natural flow of the speech. During the speaking tasks, they used such fillers, fixed expressions and compensatory strategies to speak as 
smoothly and effortlessly as possible. In the post- task phase, as the students listened to the selected online podcasts, they were asked to identify the techniques and strategies followed by the speaker(s) to maintain fluency. For further fluency practice, on the e-learning web-site, students- in their collaborative groups- were asked to speak non-stop for two minutes each session on a topic of their choice related to their everyday life. Examples of these topics included family relations, sports, shopping, vacations, travel, future careers, friends, fashion, technology, customs, traditions, the weather, clothing, food, media, cinema, university life, festivals and celebrations.

With regard to the speaking sub-skill of pragmatic competence, the proposed program had a large effect size on developing that skill among the experimental group students. In the pre- task phase, these students were asked- in their collaborative groups- to identify the functions of specific expressions in the sample online debates, oral presentations and digital stories. During speaking, they used such expressions to perform their intended functions. In the post- task phase, students listened attentively to the selected ten podcasts to identify how the speaker(s) used speech to perform the functions of (i) agreeing, (ii) disagreeing, (iii) arguing for or against a given idea through providing support arguments and refuting counter arguments, (iv) discussing the causes, effects and solutions of given problems, (v) suggesting new solutions to address the specified problems and (vi) retelling as well as commenting on given stories. Furthermore, in the post- task further practice step, they were required- in their collaborative groups- to tell what they would say in given situations to perform the previously highlighted functions. The situations activity was uploaded by the researcher on the course e-learning web-site.

To enhance the learners' speaking sub-skill of ideas development and comprehensibility, students were required to analyze and examine the sample online debates, oral presentations and digital stories to see how far they were well-developed, coherent, cohesive and comprehensible. During- speaking, they co-ordinated their speech to ensure that it was well-developed and comprehensible. In the post- task phase, they evaluated the selected online podcasts according to the same criteria providing examples from the podcasts to support their answers. In addition, in the post-task e-learning fluency activity -where students were asked to speak non-stop in their collaborative groups about an area of their choice- they were, also, required to make sure that their speech was as coherent, cohesive, well-developed and comprehensible as possible. 


\section{Ebtihal A. Helal, Ph.D.}

\section{Conclusions}

Based on the results of the current study, the following conclusions can be made:

1. The current study provided evidence for the effectiveness of the proposed Internet- based collaborative tasks program in developing EFL first year university level intensive English course students' speaking sub-skills.

2. There is also evidence that using consciousness- raising activities and offering students enough time to prepare for their speaking tasks enhance the quality of their public speaking performance.

3. This study provided tangible support to the notion that Internet sources whether audio, written, visual or audio-visual enrich the students' speaking experience and facilitate their speaking tasks.

4. Incorporating varied authentic speaking tasks that suit EFL university level cognitive maturation maintains their interest and fosters their motivation, thus enhancing their oral performance.

5. Online digital stories arouse EFL students' interest and make them more willing to practise speaking to comment on the story incidents, characters, settings or the narrator's point of views.

6. Using online sources for debating and giving multimedia oral presentations offers EFL learners with up-to-date information that makes their speech more convincing and appealing.

7. The post-task phase helps EFL learners to reflect upon their speaking performance and further practise the necessary sub-skills, thus enhancing their overall speaking ability.

\section{Recommendations}

In the light of the present study significant results, the following recommendations are made:

1. More time should be dedicated to practising speaking among EFL university level learners where real- life tasks with clear outcomes are prioritized.

2. EFL university level learners should collaborate using varied up-todate online sources to foster their speaking skill.

3. Debates, oral presentations and digital storytelling should be purposefully practised by EFL university level learners to enhance their oral proficiency. 
4. EFL learners should be given enough time to reflect upon their speaking performance and practise relevant linguistic items in the post- task stage.

5. EFL teachers should exert more efforts to cultivate a culture of collaboration and interdependence among their university level students to help them become more responsible learners.

6. More attention should be paid to the speaking sub-skills of fluency, pronunciation and pragmatic competence.

7. Student- teachers and teachers should be aware of the speaking subskills necessary for each stage so that they can better develop and evaluate these skills among their students.

8. Teachers' role as guides, facilitators and scaffolders should be further emphasized in EFL speaking classes.

9. EFL students should be offered further opportunities to practise speaking sub-skills in a supportive, anxiety- free learning environment.

10. Throughout the learning process, EFL students should be given enough informative constructive feedback covering their speaking strengths, weaknesses and suggestions for future oral performance improvement.

\section{Suggestions for further studies}

1. Further research is needed to investigate the impact of creating digital stories on Egyptian EFL university level and secondary stage students' creative writing skills.

2. Further studies are needed to investigate the effectiveness of online collaborative projects in developing Egyptian EFL learners' research writing skills and cultural awareness.

3. More studies can be conducted to compare the effectiveness of varied tasks including digital storytelling, role- playing, debating and oral presentations in developing the necessary speaking skills among students of different EFL proficiency levels, age groups and populations. 


\section{Ebtihal A. Helal, Ph.D.}

4. More studies are needed to investigate the effectiveness of Internetbased collaborative tasks in developing EFL university level learners' critical thinking skills. 


\section{References}

Abdelmageed, M. \& El-Naggar, Z. (2018). Digital storytelling enhances students' speaking skills at Zewail University of Science and Technology in Egypt. In E. Langran \& J. Borup (Eds.), Proceedings of Society for Information Technology \& Teacher Education International Conference (pp. 278-287). Washington, D.C., United States: Association for the Advancement of Computing in Education (AACE).Retrieved from https://academicexperts.org/conf/site/2018/papers/52425/

Abdul-Ameer, M. (2014). Improving vocabulary learning through digital stories with Iraqi young learners of English at the primary level. Journal of Studies in Social Sciences, 8(2), 197- 214.

Ahmed, A.E. (2018). The impact of debate strategy on developing English vocabulary and decision making of French department students at Al-Arish faculty of education. Journal of Scientific Research in Education, 19, 657- 697.

Akbulut, N. (2014). Teaching English to young learners through taskbased language teaching. (Master's thesis), Institute of Education Sciences, Pamukkale University, Denizli, Turkey.

Alasmari, A. \& Ahmed, S. (2013). Using debate in EFL classes. English Language Teaching, 6(1), 147- 152. Retrieved from http://dx.doi.org/10.5539/elt.v6n1p147

Albino, G. (2017). Improving speaking fluency in a task- based language teaching approach: The case of EFL learners at PUNIV-Cazenga. SAGE Open, 1- 11, doi: 10.1177/2158244017691077

Al-Issa, A. S., \& Al-Qubtan, R. (2010). Taking the floor: Oral presentations in EFL classrooms. TESOL Journal,1, 227-246.

Al-Rawahi, L.S. \& Al-Mekhlafi, A.M.(2015).The effect of online collaborative project-based learning on English as a Foreign Language learners' language performance and attitudes. Learning and Teaching in Higher Education: Gulf Perspectives, 12(2). Retrieved from http://lthe.zu.ac.ae

Al-Tamimi, N. \& Attamimi, R. (2014). Effectiveness of cooperative learning in enhancing speaking skills and attitudes towards learning English. International Journal of Linguistics. 6(4), 2745.

Arung, F. (2016). Improving the students' speaking skill through debate technique. Journal of English Education,1(1), 70- 76.

Austin, J. E. (2000). Principles for partnership. Journal of Leader to Leader. 18, 44- 50. 


\section{Ebtihal A. Helal, Ph.D.}

Bachman, L. (1990). Fundamental considerations in language testing. Oxford: Oxford University Press.

Baghdasaryan, K. (2012). The impact of digital storytelling on EFL learners' speaking skills: Reinforcing EFL learners' speaking skills by implementing technology. EDULEARN 12 Proceedings of the $4^{\text {th }}$. International Conference on Education and New Learning Technologies (pp.6121- 6130). Barcelona, Spain. Retrieved from https://www.amazon.com/Impact-DigitalStorytelling-Learners-Speaking/dp/3848428768

Bailey, K. M. (2006). Issues in teaching speaking skills to adult ESOL learners. In J. Comins, B. Garner \& C. Smith (Eds.), Review of adult learning and literacy, volume 6: Connecting research, policy, and practice, (pp. 113- 164). Mahwah, NJ: Lawrence Erlbaum Associates.

Baso, F. A. (2016). The implementation of the debate technique to improve students' ability in speaking. Exposure Journal, 5(2), 153-173.

Basturkmen, H. (2002). Learner observation of and reflection on spoken discourse: An approach for teaching academic speaking. TESOL Journal, 11(2), 26- 30.

Ben Alahem, S. (2013). Using oral presentation projects to help EFL learners reduce speech anxiety: A case study of second year TEFL students at Mohamed Khieder University-Biskra (Master's thesis), Faculty of Arabic Language Arts and Foreign Languages, Mohamed Khieder University, Biskra, Algeria.

Benmedjedel, K. (2017). Digital storytelling role in fostering EFL learners' writing creativity: A case study of access mini scholarship provided by the US embassy In El-Bacha school in Biskra. (Master's thesis), Faculty of Arabic Language Arts and Foreign Languages, Mohamed Kheider University of Biskra, Biskra, Algeria.

Brooks, G. \& Wilson, J. (2014). Using oral presentations to improve students' English language skills. Kwansei Gakuin University Humanities Review, 19, 199- 212.

Brown, H. D. (2007a). Teaching by principles: An interactive approach to language pedagogy. ( $2^{\text {nd }}$. ed.). New York, N.Y: Pearson Longman.

Brown, H.D. (2007b). Principles of language learning and teaching. $\left(5^{\text {th }}\right.$.ed.). New York: Pearson Longman.

Burek, D. \& Losos, C. (2014). Debate: Where speaking and listening come first. Voices from the Middle, 22(1), 49- 57. 
Burns, A \& Joyce, H. (1997). Focus on speaking. Sydney: National Center for English Language Teaching and Research.

Bygate, M. (1998). Theoretical Perspectives on Speaking. Annual Review of Applied Linguistics. 18, 20-42.

Bygate, M., Skehan, P. \& Swain, M. (2001). (Eds.). Researching pedagogic tasks: Second language learning, teaching and testing . London: Longman.

Bygate, M. (2009). Teaching the spoken foreign language. In K. Knapp \& B. Seidlhofer (Eds.), Handbook of Foreign Language Communication and Learning (6 ed., pp. 401-438). (Handbooks of Applied Linguistics). Berlin: Mouton de Gruyter.

Canale, M. \& Swain, M. (1980). Theoretical bases of communicative approaches to second language teaching and testing. Applied Linguistics, 1(1), 1- $47 . \quad$ Retrieved from http://dx.doi.org/10.1093/applin/I.1.1

Canale, M. (1983). From communicative competence to communicative language pedagogy. . In J. C. Richards, \& R. W. Schmidt (Eds.), Language and Communication. (pp.2- 14). London: Longman.

Canale, M. (1984). Considerations in the testing of reading and listening proficiency. Foreign Language Annals, 17(4), 349. Retrieved from https://www.learntechlib.org/p/136228/

Cardona, K., G. (2016). Implementation of task- based language learning approach to develop oral production. Retrieved from http://aprendeenlinea.udea.edu.co/boa/contenidos.php/5a1bb944c ed5a99060afacb64fba4d72/1252/1/contenido/

Carter, R. \& McCarthy, M. (1995). Grammar and the spoken language. Applied Linguistics, 16(2), 141-158.

Carter, R. \& McCarthy, M. (1997). Exploring spoken English. Cambridge: Cambridge University Press.

Carter, R. \& Nunan, D. (2004). Teaching English to speakers of other languages. Cambridge: Cambridge University Press.

Celce-Murcia. M. (2001). Teaching English as a second or foreign language $\left(3^{\text {rd }}\right.$. ed.). Boston: Heinle \&Heinle.

Educational Uses of Digital Storytelling. (2019). About digital storytelling: The seven elements of digital storytelling. Retrieved from 


\section{Ebtihal A. Helal, Ph.D.}

https://digitalstorytelling.coe.uh.edu/page.cfm?id=27\&cid=27\&s ublinkid $=31$

Chamot, A. U. \& O'Malley, J. M. (1994). The CALLA handbook. New York: Addison-Wesley.

Chaney, A.L. \& Burk, T.L. (1998). Teaching Oral Communication in Grades K-8. Boston: Allyn \&Bacon.

Choi, J. (2008). The role of online collaboration in promoting ESL writing. English Language Teaching, 1(1), 34- 49.

Christiansen, M. S. \& Koelzer, M. (2016). Digital storytelling: Using different technologies for EFL. MEXTESOL Journal, 40(1), Retrieved from

http://mextesol.net/journal/index.php?page=journal\&id_article=1 338

Cizinauskiene, J., Daubariene, A. \& Marcinkoniene, R. (2002). Collaborative activities in the development of writing skills using Internet- based platform. Studies about Languages, 2, 69- 74.

Córdoba Zúñiga, E. (2016). Implementing task-based language teaching to integrate language skills in an EFL program at a Colombian university. Profile Issues in Teachers' Professional Development, 18(2), 13-27.

Retrieved from https://doi.org/10.15446/profile.v18n2.49754.

Cornbleet, S. \& Carter, R. (2001). The language of speech and writing. London: Routledge.

Coşkun, A. (2016). Benefits of out- of- class speaking activities for EFL students. Uluslararası Türkçe Edebiyat Kültür Eğitim Dergisi, 5(3), 1448- 1464.

Davidson, B. (1995). Critical thinking education faces the challenge of Japan. Inquiry: Critical Thinking across the Disciplines, 17(3), 33-42.

Dekdouk, F. (2013). The effect of oral presentations on developing EGAP students' communicative competence: The case of second year undergraduate students of English at Ouargla University. (Master's thesis), Faculty of Letters and Languages, Kasdi Merbah University, Ouargla, Algeria.

Derakhshan, A. Tahery, F. \& Mirarab, N. (2015). Helping adult and young learners to communicate in speaking classes with confidence. Mediterranean Journal of Social Sciences, 6(2), 520525.

Dong, Y. (2015). Using digital storytelling to support EFL learning in China. (Master's thesis), University of Victoria, Victoria, British Colombia, Canada. 
Ducker, N. (2012). Enriching the curriculum with task-based instruction. Polyglossia, 22, 3- 13.

Dunlap, W. (1994). Generalizing the common language effect size indicator to bivariate normal correlations. Psychological Bulletin, 116 (3), 509- 511.

Ebada, M. (2009). Effectiveness of debate in EFL classes. Japan: JALT Publications.

Ellis, R. (2003). Task- based language learning and teaching. Oxford: Oxford University Press.

Erten, I. H. \& Altay, M. (2009). The effects of task- based group activities on students' collaborative behaviours in EFL speaking classes. Journal of Theory and Practice in Education, 5(1), 3352 .

Retrieved

from $\underline{\text { http://eku.comu.edu.tr/index/5/1/iherten_maltay.pdf }}$

Farabi, M., Hassanvand, S. \& Gorjian, B. (2017). Using guided oral presentation in teaching English language learners' speaking skills. Journal of Applied Linguistics and Language Learning, 3(1), 17-24. doi: 10.5923/j.jalll.20170301.03

Farahani, A. \& Nejad, M. (2009). A study of task- based approach: The effects of task- based techniques, gender and different levels of language proficiency on speaking development. Pazhuhesh-e Zabanha-ye Khareji, 49, 23- 41.

Fauzan, U. (2016). Enhancing speaking ability of EFL students through debate and peer assessment. EFL Journal, 1(1), 49- 57.

Fauzi, I. (2016). The application of multimedia- based presentation in improving students' speaking skill. Journal of ELT Research, 1(1), 103- 112.

Fonseca-Martínez, R. (2016). An attempt to increase student talking time through task- based instruction among basic level language learners at ICPNA, Cajamarca branch. (Master's thesis), Faculty of Education Science, University of Piura, Piura, Peru.

Foster, P. \& Sekhan, P. (1996). The influence of planning on performance in task- based learning. Studies in second language acquisition, 18, 299- 323.

Foster, P., Tonkeyn, A. \& Wigglesworth, G. (2000). Measuring spoken language: A unit for all reasons. Applied Linguistics, 21(3), 354375. 


\section{Ebtihal A. Helal, Ph.D.}

Fukuda, S. (2003). Attitudes toward argumentation in college EFL classes in Japan. Proceedings of the First Aisa TEFL International Conference (pp.417-418). Pusan, Korea.

Fulcher, G. (2003). Testing second language speaking. London: Longman Pearson Education.

Gamba, A. (2013). Enhancing fluency in speaking through the use of collaborative and self-directed speaking tasks. (Master's thesis), Sabana University, Chia, Cundinamarca, Colombia.

Garbati, J. \& Mady, C. (2015). Oral skill development in second languages: A review in search of best practices. Theory and Practice in Language Studies, 5(9), 1763- 1770. doi: http://dx.doi.org/10.17507/tpls.0509.01

Gerlach, J. M. (1994). Is this collaboration? In K. Bosworth \& S. J. Hamilton (Eds.), Collaborative learning: Underlying processes and effective techniques (pp. 5- 14). San Francisco: Jossey-Bass Publishing.

Gutiérrez, D. (2005). Developing oral skills through communicative and interactive tasks. Profile, 6, 83- 96.

Hamouda, A. (2016). The impact of task- based instruction on developing Saudi university EFL students' English speaking skills. Faculty of Education Scientific Journal, Assiut University, 32(2), 1- 80.

Haroun, A. (2012). The effectiveness of teaching digital stories in developing EFL primary pupils' speaking skill. (Master's thesis). Faculty of Education, Ain Shams University, Cairo, Egypt.

Hasan, A. (2014). The effect of using task- based learning in teaching English on the oral performance of secondary school students. International Interdisciplinary Journal of Education, 3(2), 250264.

Hedge, T. (2000). Teaching and learning in the language classroom. Oxford: Oxford University Press.

Hendriani, S. (2014). Implementing task- based language teaching to implement the problems of teaching speaking. Ta'dib, 17(1), 7580.

Ho, P. \& Long, N. (2014). The impacts of task-based speaking activities on English majored freshmen's oral performance at Ba Ria-Vung Tau teacher training college. Journal of Science Ho Chi Minh City Open University, 3(11), 71- 82.

Hovane, M. (2009).Teaching presentation skills for communicative purposes. Kansai University Foreign Language Education Forum, 8, 35-49. 
Howarth, P. (2001). Process speaking: Preparing to repeat yourself. MET. 10(1), 39-44. $\quad$ Retrieved from https://www.learntechlib.org/primary/p/182537/

Husband, T. (2014). Developing $21^{\text {st }}$. century skills in teacher education through digital storytelling. Selected Scholarship on Teaching and Learning at Illinois State University, 2, 1-15.

Ismaili, M. (2013). The effectiveness of task- based learning in developing students' speaking skills in academic settings on the EFL classroom: A study conducted at South East European University (SEEU). Proceedings of $1^{\text {st }}$. Albania International Conference on Education (AICE), pp. 291- 299. Retrieved from https://scinapse.io/papers/2787729861

Ji, K. (2014). Effects of a task- based approach to public speaking instruction. Chinese Journal of Applied Linguistics, 37(1), 21 - 32. doi: https://doi.org/10.1515/cjal-2014-0002

Johnson, D. W. , Johnson, R. T. , Stanne, M. B. \& Garibaldi, A. (1990). Impact of group processing on achieving in cooperative groups. $J$ Soc Psycho, 130(4), 507- 516.

Kara, E., Ayaz, A. \& Dündar, T. (2017). Challenges in EFL speaking classes in Turkish contexts. European Journal of Language and Literature Studies, 8(1), 66- 74.

Kim, S.H.(2014). Developing autonomous learning for oral proficiency using digital storytelling. Language Learning \& Technology, 18(2), 20-35. Retrieved from http://ltt.msu.edu/issues/june2014/action1.pdf

King, J. (2002). Preparing EFL learners for oral presentations. Dong Hwa Journal of Humanistic Studies, 4, 401-418.

Kirkgöz, Y. (2011). A blended learning study on implementing video recorded speaking tasks in task-based classroom instruction. TOJET: The Turkish Online Journal of Educational Technology, 10(4), 1- $13 . \quad$ Retrieved from http://www.tojet.net/articles/v10i4/1041.pdf

Kobayashi, M. (2003). The role of peer support in ESL students' accomplishment of oral academic tasks. The Canadian Modern Language Review, 59 (3), 337- 368.

Krashen, S. (1982). Principles and practice in second language acquisition. Oxford: Pergamon.

Krieger, D. (2005). Teaching debate to ESL students: A six-class unit. The Internet TESL Journal, 11(2), Retrieved from http://iteslj.org/Techniques/Krieger-Debate.html 


\section{Ebtihal A. Helal, Ph.D.}

Kuśnierek, A. (2015). Developing students' speaking skills through roleplay. World Scientific News, 1, 73- 111.

Laal, M. \& Laal, M. (2012). Collaborative Learning: What is it? Procedia-Social and Behavioral Sciences, 31, 491- 495.

Larsen-Freeman, D. (2011). Techniques and principles in language teaching. $\left(3^{\text {rd }}\right.$. ed.). Oxford: Oxford University Press.

Littlewood, W. (1998). Foreign and second language learning. Cambridge: Cambridge University Press.

Long, M. H. (1989). Task, group and task-group interactions. University of Hawaii's Working Papers in ESL, 8(2), 1-26.

Long, M. H. (1996). The role of the linguistic environment in second language acquisition. In W. Ritchie \& T. Bhatia (Eds.), Handbook of second language acquisition (pp. 413- 468). New York: Academic Press.

Luoma, S. (2004). Assessing speaking. Cambridge: Cambridge University Press.

McGreger, J. (1990). Collaborative learning: Shared inquiry as a process of reform. New Directions for Teaching and Learning (The Changing Face of College Teaching),42, 19- 30. Retrieved from https://doi/pdf/10.1002/t1.37219904204

Mazdayasna, G. (2012). Objective assessment of oral presentations and EFL learners' speaking development. Sheikhbahaee EFL Journal, 1(1), 23-38.

Mennaai, S. (2013). Developing the students' speaking skill through communicative language teaching: A case study of second year LDM English at Mohamed khieder Beskra University, ( Master's thesis), Faculty of Letters and Languages, Mohamed Khieder University of Beskra, Beskra, Algeria.

Miles, R. (2009). Oral presentations for English proficiency purposes. Reflections on English Language Teaching, 8(2), 103-110.

Ming, Z. X. (2005). Developing oral presentation skill in ELT classroom. CELEA Journal, 28(2), 118- 120.

Mohammadipour, M. \& Rashid, S. (2015).The impact of task -based instruction program on fostering ESL learners' speaking ability: A cognitive approach. Advances in Language and Literary $\begin{array}{llllll}\text { studies } \quad(A L L S), & 6 & (2), & 113- & 126 . & \text { doi: }\end{array}$ 10.7575/aiac.alls.v.6n.2p.113

Morse, K. G. (2011). Debate: A tool for language learning. Journal of Border Educational Research, 10, 108- 119. 
Mostafa, M. (2018). The effect of storytelling (ST) versus digital storytelling (DST) on developing the English oral communication performance of primary school pupils. (Doctoral dissertation). Arab Studies and Researches Institute, Arab League, Cairo, Egypt.

Munirah, M. \& Mushin, M. (2015). Using task- based approach in improving the students' speaking accuracy and fluency. Journal of Education and Human Development, 4(3), 181- 190. doi: 10.15640/jehd.v4n3a19

Murad, T. (2009). The effect of task-based language teaching on developing speaking skills among the Palestinian Secondary EFL students and their attitudes towards English. (Doctoral dissertation), Faculty of Education, Yarmouk University, Irbid, Jordan.

Nation, I. \& Newton, J. (2009). Teaching ESL/ EFL listening and speaking. New York: Routledge.

Nisbett, R. E. (2003). The geography of thought. New York: The Free Press.

Nunan, D. (1989). Designing tasks for communicative classrooms. Cambridge: Cambridge University Press.

Nunan, D. (1991). Communicative tasks and the language curriculum. TESOL Quarterly, 25(2), 279- 295.

Nunan, D. (1992). Collaborative language learning and teaching. Cambridge: Cambridge University Press.

Nunan, D. (1999). Second language teaching and learning. Boston: Heinle \& Heinle Publishers.

Nunan, D. (2004). Task-based language teaching. Cambridge: Cambridge University Press.

Osborn, M., Osborn, S. \& Osborn, R. (2009). Public speaking. $\left(8^{\text {th }}\right.$.ed.). New York: Pearson

Pantiz, T. (1999). Collaborative versus cooperative learning: $A$ comparison of the two concepts which will help us understand the underlying nature of interactive learning. Retrieved from http://home.capecod.net/ tpantiz/tedsarticles/coopdefinition.htm

Pardo, B. (2014). Digital storytelling: A case study of the creation and narration of a story by EFL learners. Digital Education Review, 26, 74- 84. Retrieved from http://greav.ub.edu/der 


\section{Ebtihal A. Helal, Ph.D.}

Pattenpitchet, F. (2011). The effects of using collaborative learning to enhance Students' English speaking achievement. Journal of College Teaching and Learning, 8(11), 1-10.

Pop, A. (2012). Enhancing English language writing and speaking through digital storytelling. Proceedings of The $7^{\text {th }}$.International Conference on Virtual Learning (pp.453- 458), University of Bucharest and "Transilvania" University of Brasov, Romania.

Promruang, J. (2012). The use of task-based learning to improve English listening and speaking abilities of Mattayomsuksa 1 students at Piboonprachasan school. (Master's thesis), Srinakharinwirot University, Bangkok, Thailand.

Rahimi, M. \& Yadollahi, S. (2017). Effects of offline vs. online digital storytelling on the development of EFL learners' literacy skills. Cogent Education, 4, 1- 13, Retrieved from http://dx.doi.org/10.1080/2331186X.2017.1285531

Razmi, M., Pourali, S. \& Nozad, S. (2014). Digital storytelling in EFL classroom (oral presentation of the story): A pathway to improve oral production. Procedia - Social and Behavioral Sciences, 98, $1541-1544$.

Richards, J. C. (2006). Communicative language teaching today. New York: Cambridge University Press.

Robin, B. R. (2006). The educational uses of digital storytelling. In C. Crawford (Ed.), Proceedings of Society for Information Technology \& Teacher Education International Conference (pp.709-716).Chesapeake, VA: AACE. Retrieved from http://digitalstorytelling.coe.uh.edu/articles/Educ-Uses-DS.pdf

Robin, B. R. (2008). Digital storytelling: A powerful technology tool for the 21 st century classroom. Theory into Practice, 47(3), 220-228. Retrieved from http://dx.doi.org/10.1080/00405840802153916

Robin, B. R. (2016). The Power of Digital Storytelling to Support Teaching and Learning. Digital Education Review, 30, 17- 29. Retrieved from http://greav.ub.edu/der/

Røkenes, F. M. (2016). Digital storytelling in teacher education: A meaningful way of integrating ICT in ESL teaching. Acta Didactica Norge, 10(2), 311- 328.

Rokni, S. \& Qarajeh, M. (2014). Digital storytelling in EFL classrooms: The effect on oral performance. International Journal of Language and Linguistics, 2(4): 252-257, doi: 10.11648/j.ijl1.20140204.12

Roselli, N. D. (2016). Collaborative learning: Theoretical foundations and applicable strategies to university. Propósitos $y$ Representaciones, 4(1), 219-280. Retrieved from 
http://dx.doi.org/10.20511/pyr2016.v4n1.90

Sabbah, S. (2015). The effectiveness of using debates in developing speaking skills among English majors at University of Palestine. (Master's thesis), Faculty of Education, Al-Azhar University, Gaza, Palestine.

Sariçoban, A. \& Karakurt, L. (2016). The use of task- based activities to improve listening and speaking skills in EFL context. Sino-US English Teaching, 13(6), 445-459. doi: 10.17265/15398072/2016.06.003

Saville-Troike, M. (2006). Introducing second language acquisition. Cambridge: Cambridge University Press.

Savingon, S. (1983). Communicative competence: Theory and classroom practice. Reading, MA: Addison-Wesley.

Scarcella, R. \& Oxford, R. (1992). The tapestry of language learning: The individual in the communicative classroom. Boston: Heinle \& Heinle Publishers.

Scrivener, J. (2005). Learning teaching: A guidebook for English language teachers. Oxford: Macmillan.

Seifeddin, A. H., Ahmed, S. Z. \& Ebriahim, E. Y.( 2015). A program based on English digital stories to develop the writing performance and reflective thinking of preparatory school pupils. Faculty of Education Magazine, 8(2), Retrieved from https://eric.ed.gov/?id=ED560675

Shumin, K. (2002). Factors to consider: Developing adult EFL students' speaking abilities. In J. C. Richards \& W. A. Renandya (Eds.). Methodology in language teaching, (pp. 204- 2011). Cambridge: Cambridge University Press.

Shuster, K., \& Meany, J. (2005). Speak out! Debate and public speaking in the middle grades. New York: International Debate Education Association.

Skehan, P. (2003). Task- Based Instruction. Language Teaching, 36, 114. doi: $10.1017 / \mathrm{s} 026144480200188 \mathrm{x}$

Smeda, N., Dakich, E. \& Sharda, N. (2014). The effectiveness of digital storytelling in the classrooms: A comprehensive study. Smart Learning Environments, 1(6), 1-22. doi: 10.1186/s40561-0140006-3

Smith, B. L. \& MacGregor, J. T. (1992). What is collaborative learning? In A. Goodsell et. al. (Eds.), Collaborative learning: A sourcebook for higher education. (pp. 10- 30). Pennsylvania: National Center on Postsecondary Teaching, Learning and as 
Assessment. Retrieved

from

http://www.cte.hawaii.edu/Webster101/docs/ED357705.pdf

Somdee, M. (2012). Developing English language speaking skills of Thai undergraduate students by digital storytelling through websites. (Master's thesis).Suranaree University of Technology, Thailand. Retrieved from

http://sutir.sut.ac.th:8080/sutir/bitstream/123456789/4169/2/Fullt ext.pdf

Sotoudehnama, E. \& Hashamdar, M. (2016). Oral presentation vs. free discussion: Iranian intermediate EFL learners' speaking proficiency and perception. Applied Research on English Language, 5(2), 211-236.

Stewart, T. (2003). Debate for ESOL students. TESOL Journal, 12(1), 915.

Retrieved from https:doi/abs/10.1002/j.19493533.2003.tb00114.x

Swain, M. (1995). Three functions of output in second language learning. In G. Cook \& B. Seidlehofer (Eds.). Principle and practice in applied linguistics: Studies in honour of H.G. Widdowson (pp.245-256), Oxford: Oxford University Press.

Swain, M. (2005). The output hypothesis: Theory and research. In E. Hinkel (Ed.), Handbook of research in second language teaching and learning (pp. 471- 483). Mahwah, NJ: Lawrence Erlbaum Associates.

Tahriri, A. , Tous, M. \& MovahedFar, S. (2015). The impact of digital storytelling on EFL learners' oracy skills and motivation. International Journal of Applied Linguistics and English Literature (IJALEL). 4(3),144- 153, Retrieved from http://dx.doi.org/10.7575/aiac.ijalel.v.4n.3p.144

Taiwari, K. \& Mani, K. R. (2017). Task-based language teaching: Its implementation to improve speaking skills of rural school students- A case study. IOSR Journal of Humanities and Social Science, 22 (8), 16- 21, doi: 10.9790/0837-2208061621

Tarone, E. \& Yule, G. (1989). Focus on the language learner: Approaches to identifying and meeting the needs of second language learners. Oxford: Oxford University Press.

Tiba, C., Condy, J., Chigona, A. \& Tunjera, N. (2015). Digital storytelling as a tool for teaching: Perceptions of pre-service teachers. TD The Journal for Transdisciplinary Research in Southern Africa, 10(3), 285-301. 
Torky, S. (2006). The effectiveness of a task-based instruction program in developing English language speaking skills of secondary stage students. (Doctoral dissertation), Women's College for Arts, Science and Education, Ain Shams University, Cairo, Egypt.

Ur, P. (1996). A course in language teaching: Practice and theory. Cambridge: Cambridge University Press.

Verdugo, D.R. \& Belmonte, I.A. (2007). Using digital stories to improve listening comprehension with Spanish young learners of English. Language Learning \& Technology, 11(1), 87101. Retrieved from https://www.learntechlib.org/p/74416/

Vygotsky, L. (1978). Mind in society: The development of higher psychological processes. Cambridge, MA: Harvard University Press.

Wahyuni \& Sarosa, T. (2017). An action research: Project-based digital storytelling to promote ESL students' digital literacy. Advances in Social Science, Education and Humanities Research (ASSEHR), 109, 303- 308.

Warschauer, M., Shetzer, H. \& Meloni, C. (2000). Internet for English teaching. Virginia: Teachers of English to Speakers of Other Languages, Inc.

Willis, J. (1996). A framework for task-based learning. London: Longman.

Willis, D. \& Willis, J. (2007). Doing task-based teaching. Oxford: Oxford University Press.

$\mathrm{Xu}, \mathrm{J}$. (2016). The relationship between the use of speaking strategies and performance on ILETS speaking test: A study on Chinese college students. International Journal for $21^{\text {st }}$. Century Education, 3(2), 69- 96.

Yahay, M. \& Kheirzadeh, S. (2015). The Impact of oral presentation on fluency and accuracy of Iranian EFL learners' speaking. Journal of Applied Linguistics and Language Research, 2(5), 114- 123.

Yang, Y. C. \& Wu, W., I. (2012). Digital storytelling for enhancing student academic achievement, critical thinking, and learning motivation: A year-long experimental study. Computers \& Education, 59(2), 339-352. doi: 10.1016/j.compedu.2011.12.012

Yousif, A. (2017). The effect of communicative task- based instruction on developing students' oral communication skills at Sudanese Universities: A case study of the first year-College of Languages, Sudan University for Science and Technology. (Doctoral 


\section{Ebtihal A. Helal, Ph.D.}

dissertation), College of Graduate Studies, Sudan University for Science and Technology.

Yule, G. (1996). Pragmatics. Oxford: Oxford University Press.

Yule, G. (2010). The study of language. $\left(4^{\text {th }}\right.$.ed.). Cambridge: Cambridge University Press.

Živković, S. (2014). The importance of oral presentations for university students. Mediterranean Journal of Social Sciences, 5(19), 468475. doi: 10.5901/mjss.2014.v5n19p468 